\title{
NÍVEIS DE BORO, COBRE E ZINCO EM SOLUÇÃO NUTRITIVA E EM DOIS SOLOS PARA O MILHO
}

\author{
REYNALDO ROCHA BELTRÁN
}

Engenheiro Agrônomo

Orientador: Prof. Dr. QUIRINO AUGUSTO DE CAMARGO CARMELLO

Tese apresentada à Escola Superior de Agricultura "Luiz de Queiroz", Universidade de São Paulo, para obtenção do título de Doutor em Agronomia, Área de Concentração: Solos e Nutrição de Plantas

PIRACICABA

Estado de São Paulo - Brasil

Dezembro - 1998 


\section{Dados Internacionais de Catalogação na Publicação (CIP) DIVISÃO DE BIBLIOTECA E DOCUMENTAÇÃO - Campus "Luiz de Queiroz"/USP}

Rocha Beltrán, Reynaldo

Niveis de boro, cobre e zinco em soluçăo nutritiva e em dois solos para o milho I Reynaldo Rocha Beltrán. - Piracicaba, 1998.

$65 \mathrm{p}$.

Tese (doutorado) - - Escola Superior de Agricultura Luiz de Queiroz, 1998.

Bibliografia.

1. Extrator quimico 2. Fertilidade do solo 3. Micronutriente 4. Milho 5. Solução nutritiva I. Titulo

CDD 633.15 
Dedico

\section{À minha filha Maristela}

À minha esposa Marli

Aos meus pais Daria e Gerardo

Aos meus irmãos Willma e Felix

À minha avó Simona (in memorian)

Com amor 


\section{AGRADECIMENTOS}

- À Escola Superior de Agricultura "Luiz de Queiroz" pela boa acolhida durante o curso.

- Ao Conselho de Desenvolvimento Tecnológico e Científico - CNPq, pela bolsa concedida.

- Ao Prof. Dr. Quirino Augusto de Camargo Carmello pela valiosa orientação.

- Aos Professores Takashi Muraoka e Rivaldo V. dos Santos, pela amizade e pelas sugestões na fase final da tese.

- Aos Professores Luis Ignácio Prochnow e Jorge de Castro Kiehl pela amizade e ensinamentos durante o estágio no Programa de Aperfeiçoamento de Ensino.

- Aos professores de curso pelos ensinamentos.

- Aos funcionários de Departamento de Química - Setor de Nutrição Mineral de Plantas: Ednéia C. S., Giovana, Mondoni, Lourdes, Lúcia H. S. P. Forti, Mirtes V. Sesso, Nivanda M. de Moura e Sueli M. A. C. Bovi, pelo apoio na execução das análises e nos trabalhos em geral.

- À Dra. Cleide Abreu, Pesquisadora do IAC, pelas sugestões.

- Ao Sr. Luís Zetten, por permitir a coleta das amostras de terra usadas no Experimento.

- Aos amigos, Ana Rosa, Cláudia, Cristina, Carla, Luthieta, Rosa, Zilda, Teresinha, Gláucia, Alberto, Adônis, Antônio, César, Cláudio, Fábio, Jonas, Marcos, Reges, João Batista e Waldsmiller pelo excelente convívio.

- Aos funcionários da Biblioteca Central da ESALQ/USP, pelo excelente atendimento e à Eliana pela revisão das referências bibliográficas. 


\section{SUMÁRIO}

Página

SUMÁRIO...................................................................................... vii

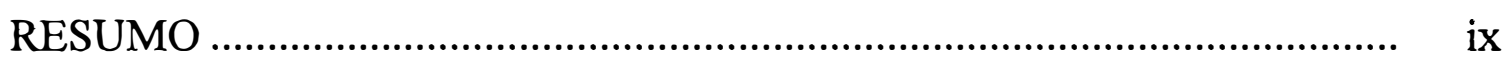

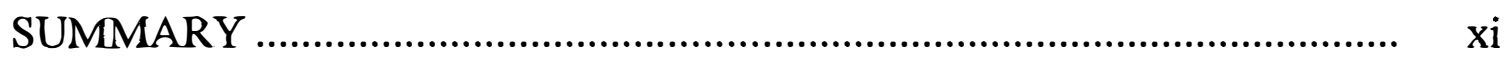

1 INTRODUÇÃO......................................................................... 1

2 REVISÃO DE LITERATURA ............................................................. 4

2.1 Essencialidade e efeito dos micronutrientes............................................ 5

2.1.1 Boro ........................................................................................ 5

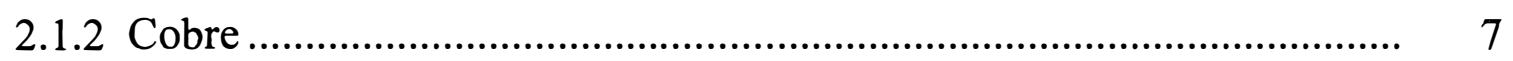

2.1.3 Zinco.............................................................................. 8

2.2 Disponibilidade e resposta aos micronutrientes .................................... 11

2.3 Extratores químicos para micronutrientes do solo ................................. 12

2.4 Níveis críticos e adequados no solo ................................................... 14

2.5 Diagnose foliar .............................................................................. 16

3 MATERIAL E MÉTODOS.......................................................... 18

3.1 Localização................................................................................. 18

3.2 Experimento 1 ........................................................................... 18

3.2.1 Condições de instalação e condução do experimento ............................ 18

3.2.2 Tratamentos, solução nutritiva e delineamento experimental.............. 19

3.2.3 Colheita, moagem e acondicionamento do material vegetal................ 19

3.3 Experimento 2 ........................................................................ 20

3.3.1 Amostragem e análise dos solos................................................... 20

3.3.2 Tratamentos ............................................................................ 20

3.3.3 Instalação e condução do experimento................................................ 21

3.3.4 Diagnose foliar ........................................................................ 22

3.3.5 Colheita, moagem e acondicionamento do material vegetal................ 23

3.3.6 Determinações no solo ..................................................................... 23

3.4 Determinações no material vegetal (Experimentos 1 e 2)....................... 24

3.4.1 Produção de material vegetal seco ....................................................... 24

3.4.2 Composição mineral ......................................................................... 25

3.5 Avaliação dos resultados ...................................................................... 25

4 RESULTADOS E DISCUSSÃO ........................................................ 26

4.1 Experimento em solução nutritiva........................................................ 26 


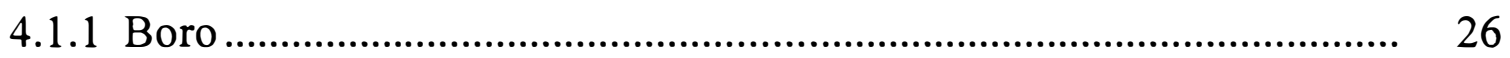

4.1.2 Cobre …........................................................................ 28

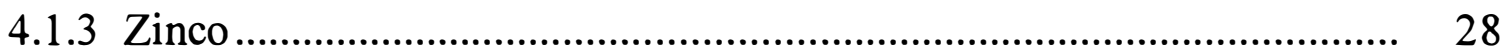

4.2. Experimento em solos ................................................................. 31

4.2.1 Análise dos solos após a calagem .............................................. 31

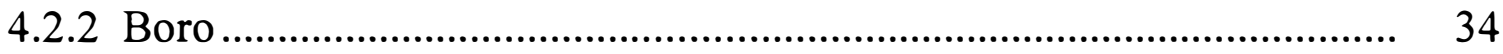

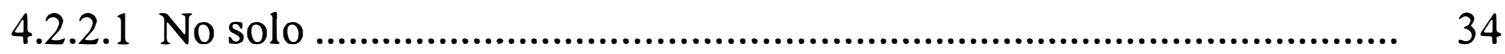

4.2.2.2 Na parte aérea da planta .................................................................. $\quad 35$

4.2.2.2.1 Na folha diagnóstica ................................................................... 35

4.2.2.2.2 Na planta colhida 30 dias após a emergência................................. 35

4.2.2.2.3 Na planta colhida no final do experimento ................................... 36

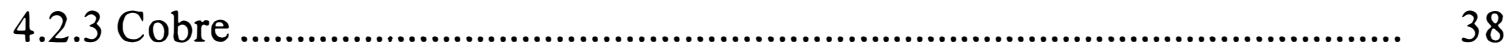

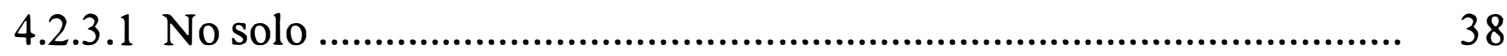

4.2.3.2 Na parte aérea da planta ............................................................... 39

4.2.3.2.1 Na folha diagnóstica ................................................................. 39

4.2.3.2.2 Na planta colhida 30 dias após a emergência................................ 40

4.2.3.2.3 Na planta colhida no final do experimento ................................... 40

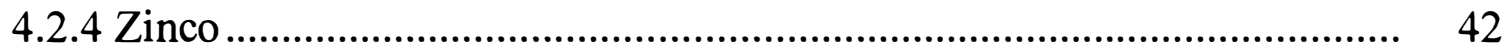

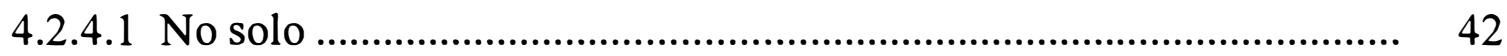

4.2.4.2 Na parte aérea da planta .............................................................. 43

4.2.4.2.1 $\mathrm{Na}$ folha diagnóstica .................................................................... 43

4.2.4.2.2 Na planta colhida 30 dias após a emergência................................. 44

4.2.4.2.3 Na planta colhida no final do experimento .................................... 45

4.2.5 Avaliação de extratores para zinco e cobre........................................ 48

4.2.5.1 Cobre ................................................................................... 48

4.2.5.2 Zinco............................................................................... 49

5 CONCLUSÕES ......................................................................... 58

REFERÊNCIAS BIBLIOGRÁFICAS ............................................... 59 


\title{
NÍVEIS DE BORO, COBRE E ZINCO EM SOLUÇÃO NUTRITIVA E EM DOIS SOLOS PARA O MILHO
}

\author{
Autor: REYNALDO ROCHA BELTRÁN \\ Orientador: Prof. QUIRINO AUGUSTO DE CAMARGO CARMELLO
}

\section{RESUMO}

O milho é tradicionalmente o cereal mais plantado, sendo cultivado em praticamente todas as regiões do Brasil. Embora o Brasil seja um dos maiores produtores mundiais de milho, a produtividade nacional é ainda uma das mais baixas do continente. A produtividade da cultura está intimamente relacionada com a nutrição adequada das plantas e, os micronutrientes têm importância relevante, já que são menos estudados que os macronutrientes. A produção de material vegetal seco e a absorção dos nutrientes pelas plantas podem ser diferentes, em função dos níveis desses nutrientes na solução nutritiva e, em cada tipo de solo. Com base nessa afirmação, realizaram-se experimentos em casa-devegetação, em condições de solução nutritiva e em dois tipos de solo (Areia Quartzosa e Podzólico Vermelho-Amarelo), utilizando-se o cultivar de milho AG-303, com duas plantas por vaso, avaliou-se o efeito dos níveis de cada um dos nutrientes boro, cobre e zinco. O experimento em solo foi instalado em delineamento estatístico de blocos ao acaso com quatro repetições. Cada unidade experimental constituiu-se de um vaso de plástico com $3,2 \mathrm{dm}^{3}$ de terra. Os blocos foram constituídos por quatro níveis de cada nutriente, em $\mathrm{mg} \mathrm{dm}^{-3} \mathrm{de}$ terra, sendo para o B: $0,0,35 ; 0,70$ e 1,40; para o $\mathrm{Cu}: 0 ; 0,5 ; 1,0$ e 2,0 e, para o $\mathrm{Zn}: 0 ; 0,7 ; 1,4$ e 2,8 . O experimento em solução nutritiva foi instalado em delineamento inteiramente casualisado com quatro repetições. Foram utilizados cinco níveis de cada nutriente, em $\mathrm{mg} \mathrm{L}^{-1}$, sendo para o $\mathrm{B}$ : $0 ; 0,25 ; 0,5 ; 1,0$ e 2,0; 
para o $\mathrm{Cu}: 0 ; 0,015 ; 0,020 ; 0,025$ e 0,030 e, para o $\mathrm{Zn:} 0 ; 0,05 ; 0,10 ; 0,20$ e 0,30 . Os nutrientes foram fornecidos como: ácido bórico $\left(\mathrm{H}_{3} \mathrm{BO}_{3}\right)$, sulfato de cobre $\left(\mathrm{CuSO}_{4} \cdot 5 \mathrm{H}_{2} \mathrm{O}\right)$ e sulfato de zinco $\left(\mathrm{ZnSO}_{4} \cdot 7 \mathrm{H}_{2} \mathrm{O}\right)$, para $\mathrm{B}, \mathrm{Cu}$ e $\mathrm{Zn}$ respectivamente. Antes da calagem, ao final do período de incubação e após a colheita das plantas de milho, os nutrientes $\mathrm{Cu}, \mathrm{Zn}, \mathrm{Fe}$ e $\mathrm{Mn}$ foram extraídos do solo com DTPA-TEA e, somente após a colheita, esses nutrientes foram extraídos com: DTPA-TEA, $\mathrm{HCl}$ 0,1M, Mehlich1 e Mehlich3. O B foi extraído com água quente, antes da calagem, ao final do período de incubação e após a colheita. Os resultados, tanto do experimento em solução nutritiva, quanto do experimento em solo, foram avaliados através dos parâmetros: produção de material vegetal seco da parte aérea das plantas de milho, teores dos nutrientes e nutrientes absorvidos. A adição de boro, cobre e zinco proporcionou aumentos nos teores desses nutrientes no solo e na planta, entretanto, apenas o zinco influenciou significativamente a produção de material vegetal $\cdot$ seco. No experimento em solução nutritiva, a dose $0,1 \mathrm{mg} \mathrm{L}^{-1}$ de $\mathrm{Zn}$ foi suficiente para se obter uma produção de material vegetal seco estatisticamente semelhante à dose máxima. No experimento em solo, a dose $2,8 \mathrm{mg} \mathrm{dm}^{-3}$ de $\mathrm{Zn}$ foi a que propiciou a maior produção de material vegetal seco. O extrator que melhor se correlacionou com o cobre aplicado aos solos foi o DTPA-TEA. Nenhum dos extratores estudados se correlacionou com o cobre absorvido pelo milho. O extrator que melhor correlacionou-se com o zinco aplicado aos solos foi o $\mathrm{HCl} 0,1 \mathrm{M}$. O zinco recuperado do solo AQ pelo extrator Mehlichl correlacionou-se melhor com o zinco absorvido pelo milho. Já, no solo PV, essa correlação foi melhor para o extrator $\mathrm{HCl}$ 0,1M. O extrator DTPA-TEA teve uma boa correlação com o zinco absorvido pelo milho apenas no solo PV. 


\title{
BORON, COPPER AND ZINC LEVELS IN THE NUTRIENT SOLUTION AND IN TWO SOILS FOR MAIZE
}

\author{
Author: REYNALDO ROCHA BELTRÁN
}

Adviser: Prof. Dr. QUIRINO AUGUSTO DE CAMARGO CARMELLO

\section{SUMMARY}

Maize is traditionally the most planted cereal, being cultivated in practically all the regions of Brazil. Although the country is one of the world biggest producers of maize, the national productivity is still one of the lowest of the continent. The culture productivity is intimately related with an adequate plant nutrition and the micronutrients have high importance, since they have less studies than the macronutrients. The dry matter production of and the nutrients absorption by the plants can be different in function of the nutrient levels in the nutrient solution and in each soil type. Based on this, the experiments took place at greenhouse conditions in nutrients solution and in two soil types (Sand soil and Red-yellow Podzol), using maize (AG-303), with two plants per pot and evaluating levels of each of the micronutrient: boron, copper and zinc. The experiment in soil had a statistical design of randomized blocks with four replications. Each experimental unit was constituted by plastic containers with 3.2 $\mathrm{dm}^{3}$ of soil. The blocks were constituted by four levels of each micronutriente, in $\mathrm{mg} \mathrm{dm}{ }^{-3}$ of soil, being for $\mathrm{B}$ : 0, 0.35, 0.70 and 1.40; for $\mathrm{Cu}: 0,0.5,1.0$ and 2.0 and for $\mathrm{Zn:} 0,0.7 ; 1.4$ and 2.8. The experiment in nutrient solution was installed in entirely randomized design with four replications. Five levels of each nutrient 
were used, in $\mathrm{mg} \mathrm{L}^{-1}$, being for B: 0, 0.25. 0.5, 1.0 and 2.0, for $\mathrm{Cu}$ : 0, 0.015; $0.020,0.025$ and 0.030 and for $\mathrm{Zn}: 0,0.05,0.10,0.20$ and 0.30 . The nutrients form used were: boric acid $\left(\mathrm{H}_{3} \mathrm{BO}_{3}\right)$, copper sulfate $\left(\mathrm{CuSO}_{4} .5 \mathrm{H}_{2} \mathrm{O}\right)$ and zinc sulfate $\left(\mathrm{ZnSO}_{4} .7 \mathrm{H}_{2} \mathrm{O}\right)$, for $\mathrm{B}, \mathrm{Cu}$ and $\mathrm{Zn}$, respectively. Before liming, at the end of the incubation period and after harvest of maize, the nutrients $\mathrm{Cu}, \mathrm{Zn}, \mathrm{Fe}$ and Mn were extracted from the soil with DTPA-TEA and only after the harvest, the nutrients were extracted by: DTPA-TEA, $\mathrm{HCl} 0.1 \mathrm{M}$, Mehlich1 and Mehlich3. Boron was extracted with hot water, before the liming, at the end of the incubation period and after harvest. The results of the experiment in nutrients solution, and of the experiment in soils as wall, were evaluated with the parameters: dry matter production of above ground part of maize plants, nutrient concentration and the amount of absorbed nutrients. The boron, copper and zinc addition provided increases in the nutrient contents in soil and in plant, but, only zinc influenced significantly the dry matter production. In the nutrient solution experiment, the level $0.1 \mathrm{mg} \mathrm{L}^{-1}$ of $\mathrm{Zn}$ was enough to obtain dry matter production statistically the same to the maximum level. In the soil experiment, the level $2.8 \mathrm{mg} \mathrm{dm}^{-3}$ of $\mathrm{Zn}$ had the highest dry matter production. The extractant which better correlated with the applied copper to the soils was DTPA-TEA. None of the tested extractants correlated with the copper absorbed by maize. The extractant which better correlated with the zinc applied to the soils was $\mathrm{HCl}$ $0.1 \mathrm{M}$. The zinc extracted from the AQ soil with Mehlichl extractant correlated better with the zinc absorbed by maize. In the PV soil that correlation was better for the $\mathrm{HCl} 0.1 \mathrm{M}$ and DTPA-TEA extractant. The DTPA-TEA extractant only had a good correlation in the PV soil. 


\section{INTRODUÇÃO}

O milho é tradicionalmente o cereal mais plantado, sendo cultivado em praticamente todas as regiões do Brasil. Embora o Brasil seja um dos maiores produtores de milho no mundo, a produtividade nacional, é ainda uma das mais baixas do continente.

Os solos do Brasil apresentam, de um modo geral, deficiência acentuada de $\mathrm{P}$, baixo conteúdo de matéria orgânica, baixa saturação por bases, saturação por alumínio relativamente elevada e, baixos teores de micronutrientes. As quantidades de micronutrientes requeridas pelas culturas são pequenas, quando comparadas com as de macronutrientes. Pequenas variações nos teores de micronutrientes do solo, podem, portanto, levar a estados de deficiência ou toxicidade, afetando sensivelmente o desenvolvimento das plantas. Os micronutrientes $\mathrm{B}, \mathrm{Cu}$ e $\mathrm{Zn}$ podem tornar-se menos disponíveis às plantas, muitas vezes devido à utilização de doses elevadas de calcário ou adubos fosfatados.

Por outro lado, a disponibilidade dos micronutrientes nos solos está relacionada com a quantidade de nutrientes em diversas formas sólidas, que estão em equilíbrio com as formas presentes na solução do solo e, com a velocidade na qual a fase sólida é renovada.

$\mathrm{O}$ incremento nos rendimentos das colheitas tem dado como resultado, uma maior atenção à necessidade de adubação com esses nutrientes. À 
medida que os rendimentos aumentam, as deficiências de micronutrientes tornamse mais freqüentes. Os maiores rendimentos também provocam uma maior remoção de nutrientes do solo. $\mathrm{Na}$ prática da adubação, a adição de micronutrientes aos adubos mais utilizados, praticamente inexiste atualmente, e isso causa preocupação, pois o esgotamento dos micronutrientes no solo torna-se inevitável.

O conhecimento das necessidades nutricionais da cultura do milho, que são determinadas pela quantidade total de nutrientes que ela precisa extrair durante seu ciclo e da época em que eles são mais exigidos pela cultura, são importantes, para se orientar o fornecimento racional de fertilizantes ao solo.

A produtividade da cultura do milho está relacionada intimamente com a nutrição adequada das plantas e, seu rendimento depende da interação de vários fatores, entre os quais a nutrição mineral, a qual requer mais estudos. $\mathrm{Na}$ nutrição mineral das plantas os micronutrientes têm importância relevante, já que são menos estudados que os macronutrientes, entretanto, do ponto de vista qualitativo, eles tem a mesma importância. Um maior conhecimento sobre o assunto facilitaria a recomendação de micronutrientes, em função da exigência das plantas e do tipo de solo.

Considerando-se todos esses aspectos, sem dúvida alguma, a adubação com micronutrientes na cultura do milho, principalmente $\mathrm{B}, \mathrm{Cu}$ e $\mathrm{Zn}$, é de fundamental importância.

A produção de material vegetal seco e a absorção dos nutrientes pelas plantas podem ser diferentes, em função dos níveis desses nutrientes na solução nutritiva e, em diferentes tipos de solo. Com base nessa afirmação, este estudo foi realizado, visando os seguintes objetivos: 
- Avaliar a absorção de nutrientes e a produção de material vegetal seco pela cultura do milho, em função dos níveis de $\mathrm{B}, \mathrm{Cu}$ e $\mathrm{Zn}$ na solução nutritiva.

- Avaliar o efeito dos micronutrientes B, Cu e $\mathrm{Zn}$ aplicados ao solo, sobre o rendimento de material vegetal seco e a composição química do milho. 


\section{REVISÃO DE LITERATURA}

Vários fatores contribuem para que a produtividade brasileira de milho não alcance patamares mais satisfatórios, sendo que, um dos principais é a utilização de pouca ou nenhuma tecnologia, em função do baixo nível de capitalização dos pequenos produtores, os quais respondem por aproximadamente $60 \%$ da produção nacional. No Norte e Nordeste, onde as técnicas de produção são rudimentares, com baixa ou nula utilização dos insumos modernos disponíveis, a situação é ainda mais grave. Nessas duas regiões, estão cerca de $30 \%$ da área plantada com milho no país, mas a produção mal alcança $10 \%$ do total, quando não ocorrem adversidades climáticas (Pinazza, 1993).

As altas produtividades na cultura do milho estão relacionadas intimamente com a aplicação de doses relativamente elevadas de fertilizantes, que podem conduzir a um suprimento desbalanceado de nutrientes, tendo como conseqüência a diminuição na produção de grãos (Büll, 1993).

O conhecimento da absorção e do acúmulo de nutrientes, nas diferentes fases do desenvolvimento da planta, é importante, porque permite determinar-se as épocas em que os nutrientes são mais exigidos e, corrigir as 
deficiências que, por ventura, venham a ocorrer durante o desenvolvimento das culturas (Barbosa Filho, 1987).

\subsection{Essencialidade e efeito dos micronutrientes}

A disponibilidade de alguns micronutrientes, tais como $\mathrm{Zn}, \mathrm{Cu}$, e B, é muito baixa nos solos do Brasil. Eles ainda são muito pouco utilizados nas adubações, apesar de serem essenciais para o bom desenvolvimento das plantas. A importância desses micronutrientes é maior em solos cultivados intensivamente, nos quais as reservas já encontram-se esgotadas.

\subsubsection{Boro}

A essencialidade do boro para a cultura do milho foi amplamente comprovada por diversos pesquisadores. Apesar disso, o milho não é considerado como uma planta das mais exigentes. $O$ aproveitamento desse nutriente é dificultado pela sua imobilidade, pois, uma vez absorvido pela planta, ele permanece imóvel, não se translocando para os outros órgãos, fazendo com que seja necessário um suprimento constante, via adubação.

As funções do B estão relacionadas com alguns processos básicos, tais como o metabolismo de carboidratos e o transporte de açúcares através das membranas, a síntese de ácidos nucleícos (RNA e DNA) e de fitohormônios, a formação das paredes celulares, a divisão celular e o desenvolvimento de tecidos (Dechen, 1988; Borkert, 1989).

A falta de $\mathrm{B}$ determina no milho uma desorganização celular nos tecidos, provocando distúrbios em diversos órgãos, que manifestam sintomas 
externos, os quais incluem um crescimento terminal reduzido e o surgimento de brotações laterais; folhas deformadas, espessas e quebradiças; pecíolos e caules com espessamento, rupturas e necrose; secamento e podridão de frutos, tubérculos e raízes. Esses sintomas manifestam-se com maior intensidade nas condições em que não se usam adubos que contenham esse nutriente, como esterco de curral, superfosfatos e salitre do Chile (Dechen, 1988).

De uma forma geral, as respostas do milho à aplicação de $\mathrm{B}$ ainda não são consistentes. Touchton \& Boswell (1975), aplicando B tanto via foliar como via solo, observaram que não houve influência sobre a produção de grãos e no conteúdo de proteína bruta; Mozafar (1989), em variedades submetidas a diversos níveis de $\mathrm{B}$, observou uma resposta positiva na produção de material vegetal seco total em apenas duas variedades.

Woodruf et al. (1987) observaram efeitos benéficos do B sobre a produção de grãos e concluíram que, as aplicações de B podem ser necessárias, quando se intensifica o uso de práticas agrícolas associadas às adubações pesadas com potássio.

Diversos trabalhos envolvendo o boro na cultura do milho não apresentaram respostas à aplicação desse micronutriente (Gallo et al., 1965; Galrão \& Mesquita Filho, 1981; Galrão, 1984; Abreu et al., 1987; Galrão, 1988). Analisando diversos trabalhos, Galrão (1988) constätou resposta da cultura do milho ao boro em poucos casos.

Gupta (1983), estudando a deficiência e toxicidade em diversas culturas, entre elas o milho, observou que a concentração $8 \mathrm{mg} \mathrm{kg}^{-1}$ de B na parte aérea, quando as plantas encontravam-se com a altura de $25 \mathrm{~cm}$, não apresentaram deficiência desse nutriente, embora esteja abaixo do nível crítico $\left(9 \mathrm{mg} \mathrm{kg}^{-1}\right)$. Isso 
indica, segundo o autor, que o milho é menos sensível à deficiência de $\mathrm{B}$ do que outras culturas.

\subsubsection{Cobre}

O teor total de cobre nos solos varia entre 2 e $100 \mathrm{mg} \mathrm{kg}^{-1}$, sendo os teores médios 20 a $30 \mathrm{mg} \mathrm{kg}^{-1}$. Entretanto, em função do material de origem do solo, esse limite pode ser ampliado para $150 \mathrm{mg} \mathrm{kg}^{-1}$ como é o caso de rochas basálticas e os ferrassolos de clima tropical. Teores totais de cobre elevados em solos, superiores a $254 \mathrm{mg} \mathrm{kg}^{-1}$, já foram encontrados em solos próximos de fundições (Baker, 1990).

A variação do teor total de cobre em solos do Estado de São Paulo situa-se entre 23 e $126 \mathrm{mg} \mathrm{kg}^{-1}$, com um teor solúvel em $\mathrm{HCl} 0,1 \mathrm{~N}$ entre $0,5 \mathrm{e}$ $14,6 \mathrm{mg} \mathrm{kg}^{-1}$ (Jacintho et al., 1969). Castro et al. (1992) determinaram os teores de cobre solúvel em solução de DTPA tamponizada com trietanolamina (TEA) a pH 7,3 em dois Latossolos sob clima tropical e encontraram valores de 0,2 a 0,6 $\mathrm{mg} \mathrm{kg}^{-1}$ na camada superficial.

Os teores normais de cobre nos tecidos das plantas variam entre 5 a $20 \mathrm{mg} \mathrm{kg}-1$. Teores menores que $4 \mathrm{mg} \mathrm{kg}^{-1}$ são encontrados em plantas deficientes. Teores de $\mathrm{Cu}$ em tecidos foliares maiores que $20 \mathrm{mg} \mathrm{kg}^{-1}$ são indicativos de toxicidade (Adriano, 1986).

O cobre na planta desempenha papel importante em diversos processos fisiológicos, tais como: fotossíntese, respiração, distribuição de carboidratos, redução e fixação de $\mathrm{N}$, metabolismo de proteínas e nas paredes celulares. Ele controla as relações de água na planta e a produção de DNA e RNA, sendo que a sua deficiência reduz marcadamente a produção de sementes, 
pelo aumento da esterilidade do grão de pólen e está envolvido, também, nos mecanismos de resistência às doenças (Dechen, 1988; Borkert, 1989).

$\mathrm{O} \mathrm{Cu}$ é exigido em quantidades muito pequenas pelo milho, porém sua falta pode provocar dificuldades no aproveitamento de diversos macro e micronutrientes.

A resposta do milho à aplicação de $\mathrm{Cu}$ ainda não está bem definida. Dragun et al. (1976), estudando o desenvolvimento de plantas de milho em função dos níveis de $\mathrm{Cu}$ em solução nutritiva, observaram uma redução no crescimento e amarelecimento das folhas em plantas deficientes em $\mathrm{Cu}$ e, que em concentrações de $\mathrm{Cu}$ acima de $0,1 \mathrm{mg} \mathrm{kg}^{-1}$ exibiram, como reflexo de toxicidade, desenvolvimento reduzido da parte aérea e paralisação no crescimento do sistema radicular. Galrão (1984) obteve um aumento na produção de grãos de milho no tratamento onde se fez adição desse micronutriente.

Estudos conduzidos com milho cultivado em diversos solos originalmente sob vegetação de cerrado (Britto, et al., 1971; Galrão \& Mesquita Filho, 1981; Galrão, 1984; Abreu et al., 1987), não mostraram efeitos da aplicação de cobre. Gallo et al. (1976), em dois experimentos conduzidos em dois locais, encontraram correlação positiva entre os níveis foliares de cobre e a produção de grãos de milho, em apenas um dos experimentos.

\subsubsection{Zinco}

O zinco é um dos micronutrientes mais exigidos pela cultura do milho. Ele tem funções metabólicas essenciais na planta e, uma das mais importantes, é participar como componente de um grande número de enzimas, tais como desidrogenases, proteinases, peptidases e fosfohidrolases. Suas funções 
básicas na planta estão relacionadas com o metabolismo dos carboidratos, das proteínas e dos fosfatos, e na formação da estrutura de auxinas, RNA e ribossomos (Borkert, 1989).

Uma das conseqüências da carência de $\mathrm{Zn}$ na planta é $o$ encurtamento dos entrenós, resultando na redução do crescimento da planta. Isso ocorre, porque o $\mathrm{Zn}$ é necessário para a produção de triptofano, que é um aminoácido precursor do AIA, hormônio vegetal promotor do crescimento (Barbosa Filho, 1987).

$\mathrm{O}$ teor de zinco presente nos solos depende da concentração de $\mathrm{Zn}$ na rocha de origem, porém também depende de fatores como $\mathrm{pH}$ e conteúdo de matéria orgânica. Estima-se que o conteúdo normal varia entre 100 a 300 mg kg1 , sendo os teores menores presentes nos solos derivados de granitos e gnaisses e os maiores, nos solos derivados de rochas sedimentares. $\mathrm{O}$ teor médio de $\mathrm{Zn}$ presente nos solos é estimado em $40 \mathrm{mg} \mathrm{kg}^{-1}$. Entretanto, em solos próximos às fundições, já foram encontrados teores de 1.000 a $10.000 \mathrm{mg} \mathrm{kg}^{-1}$ (Kiekens, 1990).

Em três solos do Estado de São Paulo, Jacintho et al. (1971) encontraram teores de $\mathrm{Zn}$ solúveis em $\mathrm{HCl}$, $1 \mathrm{~N}$ variando entre 2,4 e $5,8 \mathrm{mg} \mathrm{kg-1}^{-1}$.

$\mathrm{O}$ conteúdo de $\mathrm{Zn}$ nas plantas varia conforme a espécie, sendo algumas espécies sensíveis à deficiência desse micronutriente, entre as quais encontra-se o milho. De um modo geral, pode-se dizer que o conteúdo $\mathrm{Zn}$ na planta é considerado deficiente, quando está entre 10 a $20 \mathrm{mg} \mathrm{kg}^{-1}$ e níveis tóxicos ocorrem quando a concentração de $\mathrm{Zn}$ é maior que $400 \mathrm{mg} \mathrm{kg}^{-1}$ (Kiekens, 1990; Smilde et al., 1992; Davies, 1993).

$\mathrm{O}$ micronutriente $\mathrm{Zn}$ apresenta efeitos positivos no aumento da altura das plantas, no número de folhas, na produção de forragem e de grãos, bem 
como, no aumento do conteúdo total de $\mathrm{N}$ e de proteína nos grãos (Decaro et al., 1983).

Ritchey et al. (1986) demonstraram que existe uma correlação positiva entre a concentração de $\mathrm{Zn}$ na folha da base da espiga e a produção de grãos de milho. Liu et al. (1993), estudando o efeito da aplicação do zinco para o milho encontraram que os valores dos níveis críticos de $\mathrm{Zn}$ foram $0,6 \mathrm{mg} \mathrm{kg}^{-1}$ para solo e $20 \mathrm{mg} \mathrm{kg}^{-1}$ para os tecidos da planta.

Couto et al. (1992), trabalhando com amostras de 12 solos sob vegetação de cerrado, verificaram que a variação do nível crítico de $\mathrm{Zn}$ no solo foi de 0,8 a $4,6 \mathrm{mg} \mathrm{dm}^{-3}$ para o extrator Mehlichl e na planta, de 13 a $20 \mathrm{mg} \mathrm{kg}^{-1}$. Galrão (1995) obteve níveis críticos de $\mathrm{Zn}$ de $0,7 \mathrm{mg} \mathrm{dm}^{-3}$, no solo para o extrator Mehlich1 e de $18,5 \mathrm{mg} \mathrm{kg}^{-1}$ nas folhas de milho cultivado em LV, em condições de campo.

Com relação às recomendações para o fornecimento de $\mathrm{Zn}$ na cultura do milho, as doses podem variar de 1 a $5 \mathrm{~kg} \mathrm{ha}^{-1}\left(0,5\right.$ a $\left.2,5 \mathrm{mg} \mathrm{dm}^{-3}\right) \mathrm{de}$ $\mathrm{Zn}$, em solos deficientes em $\mathrm{Zn}$ (Volkweiss, 1991). Malavolta (1987) recomendou, para suprir as deficiências do nutriente, a aplicação de 2,3 e $4 \mathrm{~kg}$ $\mathrm{ha}^{-1}$ de $\mathrm{Zn}\left(1,0 ; 1,5\right.$ e $\left.2,0 \mathrm{mg} \mathrm{kg}^{-1}\right)$, para solos arenosos, de textura média e argilosos ou ricos em matéria orgânica, respectivamente.

Ritchey et al. (1986), em dois experimentos para avaliar o efeito das doses de $\mathrm{Zn}$, em solos sob vegetação de cerrado, na produção do milho, constataram que houve resposta do milho, e o maior incremento de produção de grãos ocorreu até a dose de $3 \mathrm{~kg} \mathrm{ha}^{-1}\left(1,5 \mathrm{mg} \mathrm{kg}^{-1}\right)$ de zinco.

Abreu et al. (1987), em um experimento de casa-de-vegetação, utilizando a técnica do elemento faltante ou diagnose por substração, verificaram que apenas a omissão de $\mathrm{Zn}$ limitou a produção de material vegetal seco. Galrão 
\& Mesquita Filho (1981) ao avaliar o efeito de micronutrientes em condições de campo, encontraram que o zinco foi o único micronutriente cuja omissão provocou um decréscimo significativo na produção de grãos de milho.

Em um experimento de campo, num Latossolo Vermelho-Amarelo, da região dos cerrados, Galrão (1995) verificou que as doses de $\mathrm{Zn}$ tiveram efeitos significativos no rendimento de grãos, nos teores de $\mathrm{Zn}$ extraídos do solo e nos teores de $\mathrm{Zn}$ nas folhas.

\subsection{Disponibilidade e resposta aos micronutrientes}

O conhecimento da ocorrência, reação e movimento dos micronutrientes no solo é fundamental para a análise de seu comportamento no sistema solo-planta. A ocorrência está muito ligada ao material de origem, ao intemperismo e à ação dos fatores formadores do solo. As reações estão relacionadas com a solubilidade dos minerais que os contêm e com a existência de material orgânico, cujos radicais e superfícies propiciam o meio adequado para o controle da disponibilidade e movimentação desses elementos na solução do solo (Camargo, 1988).

Segundo Bataglia (1988) os micronutrientes $\mathrm{Cu}$ e $\mathrm{Zn}$ são complexados pela matéria orgânica do solo e ocorrem na solução do solo principalmente como complexos solúveis. A disponibilidade do $\mathrm{B}$ é controlada principalmente pelo $\mathrm{pH}$, pela adsorção de matéria orgânica e pela umidade do solo. A diminuição da disponibilidade de $\mathrm{B}, \mathrm{Cu}$ e $\mathrm{Zn}$ pela calagem ocorre, mas, só é crítica quando o $\mathrm{pH}$ se eleva muito acima de 6, ou quando os solos são derivados de material de origem muito pobre. 
A concentração de micronutrientes solúveis em água é muito baixa. As quantidades de $\mathrm{Cu}, \mathrm{Zn}$ e B solúveis em água oscilam entre 0,09 e $0,46 \mathrm{mg} \mathrm{dm}^{-}$ $3,<0,074 \mathrm{mg} \mathrm{dm}^{-3}$ e 0,24 e $0,27 \mathrm{mg} \mathrm{dm}^{-3}$, respectivamente (Cox e Kamprath, 1983).

A cultura do milho tem baixa sensibilidade à deficiência de $\mathrm{B}$, média sensibilidade à de $\mathrm{Cu}$ e alta à de $\mathrm{Zn}$ (Martens \& Wertermann, 1991).

Em um experimento de casa-de-vegetação com a cultura do milho, utilizando a técnica de diagnóstico por subtração Dhillon et al. (1983), verificaram que a deficiência individual dos micronutrientes $\mathrm{B}, \mathrm{Cu}$ e $\mathrm{Zn}$ no meio de crescimento diminuiu significativamente o acúmulo de material vegetal seco pela parte aérea e pelas raízes das plantas de milho.

\subsection{Extratores químicos para micronutrientes do solo}

Existem poucas pesquisas no Brasil para permitir a seleção dos melhores métodos e, principalmente, o estabelecimento de limites de teores para a interpretação da análise de micronutrientes.

O propósito da análise dos solos é medir as quantidades dos nutrientes disponíveis para as plantas, contidos nos solos, com o objetivo de fornecer parâmetros para o cálculo da recomendação de adubação. Constitui, portanto, o instrumento mais importante com que conta o agricultor para definir o uso eficiente de adubos e corretivos.

A interpretação das análises de solo baseia-se em estudos de correlação e calibração com as respostas das plantas à aplicação de uma quantidade adequada de nutrientes. Lopes \& Carvalho (1988) afirmaram que esta é uma das fases mais críticas de um programa de avaliação da fertilidade do solo, 
uma vez que um resultado obtido em uma análise de solo não apresenta nenhum valor "per se", e pode ou não refletir a disponibilidade do nutriente em questão. Assim, os valores obtidos na análise do solo por um determinado método, somente tornam-se utilizáveis quando os mesmos têm correlação com as respostas de produção das culturas. Tais correlações são, em geral, obtidas em duas etapas: uma primeira, considerada exploratória, é desenvolvida em casa-de-vegetação, com um grande número de solos que apresentam amplas variações em suas propriedades e características, como por exemplo, textura, matéria orgânica, material de origem etc; e uma segunda etapa, considerada definitiva, conduzida em condições de campo, envolvendo um menor número de solos, cuidadosamente selecionados.

Os teores na solução, que representam o chamado fator intensidade, devem estar em equilíbrio com a fração dos micronutrientes da fase sólida, que representa o fator quantidade. Em geral, pela análise do solo, busca-se avaliar o fator quantidade, sendo muito difícil medir o fator intensidade.

O crescimento normal de uma planta não depende apenas da concentração, na forma disponível, de um dado nutriente no meio de crescimento, mas também das quantidades relativas dos outros elementos que estão disponíveis (Büll, 1986). Assim, o crescimento da planta em relação a um determinado nutriente é função de duas variáveis: quantidade e balanço nutricionais.

A literatura evidencia a existência de diversos métodos de extração de micronutrientes do solo. A água quente tem sido usada para B principalmente, soluções diluídas de ácidos fortes têm sido usadas para a extração de $\mathrm{Zn}$ e $\mathrm{Cu}$ e, eventualmente para B (Raij \& Bataglia, 1988).

Apesar do extrator DTPA-TEA (ácido dietileno triamino pentacético + trietanolamina) ter sido desenvolvido para uso em solos calcários (Lindsay \& 
Norvell, 1978), os estudos têm indicado que ele é aplicável aos solos ácidos, com resultados tão bons quanto nos solos alcalinos e superiores aos extratores ácidos diluídos. No Brasil, há evidências de que as soluções complexantes, como DTPATEA são melhores do que as ácidas, como Mehlichl $\left(\mathrm{HCl} \mathrm{0,05} \mathrm{mol} \mathrm{L-1}+\mathrm{H}_{2} \mathrm{SO}_{4}\right.$ 0,025 $\mathrm{mol} \mathrm{L}^{-1}$ ) e $\mathrm{HCl} \mathrm{0,1} \mathrm{mol} \mathrm{L-1} \mathrm{(Muraoka} \mathrm{et} \mathrm{al.,} \mathrm{1983;} \mathrm{Ribeiro} \mathrm{\&} \mathrm{Tucunango}$ Sarabia, 1984; Ritchey et al., 1986; Galrão, 1996).

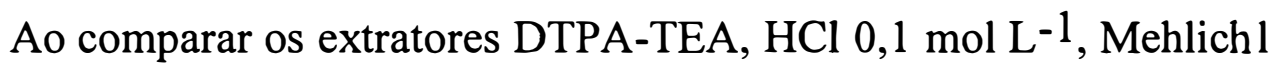
e EDTA, Bataglia \& Raij (1994) verificaram para o DTPA-TEA, coeficientes de correlação superiores aos demais, para o milho.

\subsection{Níveis críticos e adequados no solo}

No estudo da avaliação da fertilidade do solo, na fase de calibração do método de análise, são definidas as doses recomendáveis de nutrientes a serem adicionadas aos solos e os níveis críticos. As doses recomendáveis de nutrientes em casa-de-vegetação correspondem, geralmente, àquelas que proporcionam $80 \mathrm{a}$ 90\% da produção máxima, procurando-se aproximar das doses que, em condições de campo, proporcionarão a máxima eficiência econômica. O nível crítico é o teor do nutriente, no solo ou na planta, que permite separar-se populações de solos com alta probabilidade de resposta daqueles com baixa probabilidade de resposta às adições do nutriente avaliado. Pode também ser definido, como o valor da concentração do nutriente, necessária para se obter a produção com máxima eficiência econômica. Os valores obtidos por essa metodologia são variáveis, e dependem não só do método de extração e da cultura em estudo, mas, também, das características mineralógicas, físicas, químicas e físico-químicas dos solos (Alvarez V. et al., 1988). 
Os níveis de micronutrientes nos solos devem estar sempre associados aos das plantas, pois espécies vegetais e até cultivares comportam-se diferentemente diante dos teores de nutrientes no solo. Na maioria dos casos de estudos com micronutrientes, são escolhidas espécies sensíveis aos baixos teores no solo, assim os níveis críticos são normalmente altos, para as espécies ou os cultivares menos sensíveis (Raij \& Bataglia, 1991).

Os níveis críticos de micronutrientes extraídos pelo DTPA-TEA para milho, sugeridos por Lindsay \& Norvell (1978) são: $0,8 \mathrm{mg} \mathrm{kg}^{-1}$ para $\mathrm{Zn} \mathrm{e}$ $0,2 \mathrm{mg} \mathrm{kg}^{-1}$ para $\mathrm{Cu}$. Ritchey et al. (1986) verificaram também em milho, um valor muito próximo para $\mathrm{Zn}: 0,7 \mathrm{mg} \mathrm{kg}^{-1}$.

Para solos do Estado de São Paulo, foram estabelecidas classes de interpretação dos teores de micronutrientes metálicos, $\mathrm{Cu}$ e $\mathrm{Zn}$ determinados pelo método DTPA-TEA e de B pelo método da água quente (Tabela 1).

Tabela 1. Classes de interpretação de teores de micronutrientes em solos do Estado de São Paulo.

\begin{tabular}{lccc}
\hline Classes & Boro & Cobre & Zinco \\
\hline & $-0,20$ & $<0,20$ & $<0,5$ \\
Baixo & $<0,-0,60$ & $0,20-0,80$ & $0,5-1,2$ \\
Médio & $>0,60$ & $>0,80$ & $>1,2$ \\
Alto & &
\end{tabular}

Fonte: Abreu (1995).

O conteúdo total de boro no solos apresenta uma variação muito grande em função do material de origem, da região e do tipo de clima onde os solos se formaram. No solo, é considerado o elemento com maior mobilidade dentre os nutrientes e, em geral, a maior concentração desse elemento ocorre nos horizontes mais superficiais, porque a sua ocorrência está intimamente 
relacionada com o teor de matéria orgânica total, humus e teor de argila. $\mathrm{O}$ conteúdo de boro varia também em relação à textura e ao $\mathrm{pH}$. Os solos arenosos apresentam, geralmente, teores menores desse nutriente do que os argilosos (Keren \& Bingham, 1985).

Os teores totais de B no solo variam de 1 a $270 \mathrm{mg} \mathrm{kg}^{-1}$ e os valores médios encontram-se entre 20 e $50 \mathrm{mg} \mathrm{kg}^{-1}$ (Aubert \& Pinta, 1977). Segundo os mesmos autores, o $\mathrm{B}$ solúvel em água representa 1 a $3 \%$ do total e o teor disponivel para as plantas varia de 0,1 a $2 \mathrm{mg} \mathrm{kg}^{-1}$. Segundo Fleming (1980), os teores totais de B no solo estão entre 4 a $98 \mathrm{mg} \mathrm{kg}^{-1}$ e o B disponível para as plantas está entre 0,28 a $2,0 \mathrm{mg} \mathrm{kg}^{-1}$.

A concentração de um nutriente na planta é um indicador que reflete a influência de vários fatores no seu crescimento. Para o milho, a concentração crítica de Zn na parte aérea da planta, sob condições de casa-de-vegetação, está em torno de $15 \mathrm{mg} \mathrm{kg}^{-1}$ (Melsted et al., 1969; Terman et al., 1972).

\subsection{Diagnose foliar}

A diagnose foliar é um método de avaliação do estado nutricional das culturas, em que analisam-se determinadas folhas, em períodos definidos do ciclo da planta. Analisam-se as folhas, porque refletem melhor o estado nutricional, isto é, respondem mais às variações no suprimento de nutrientes (Malavolta et al., 1989).

Uma das relações mais importantes na análise das plantas para fins de diagnóstico nutricional é a que envolve a produção, a concentração de nutrientes na planta e os níveis de nutrientes no solo (Andrade et al., 1975). A relação entre o teor percentual do nutriente na folha e a produção final da planta é 
utilizada para determinar-se o chamado "nível crítico", ou a concentração ótima de nutrientes na planta. Atualmente, o conceito de "faixa crítica" tem sido mais aceito (Büll, 1993).

A concentração de nutrientes varia com a idade fisiológica da planta, e essa variação deve ser considerada para a definição da época correta de amostragem. Trani et al. (1983) recomendaram a amostragem, para o milho, dos $30 \mathrm{~cm}$ do terço basal da folha +4 , excluída a nervura central, com idade de nove semanas, enquanto que Malavolta et al., (1989) recomendaram, amostragem de folha inteira localizada abaixo da espiga, quando do aparecimento da inflorescência feminina. Em ambos os casos, coletam-se 30 folhas por hectare. 


\section{MATERIAL E MÉTODOS}

\subsection{Localização}

Foram realizados dois experimentos, em solução nutritiva (Experimento 1) e solo (Experimento 2), em casa-de-vegetação do Departamento de Química - Setor de Nutrição Mineral de Plantas, da Escola Superior de Agricultura “Luiz de Queiroz” (ESALQ/USP), em Piracicaba, São Paulo.

\subsection{Experimento 1}

\subsubsection{Condições de instalação e condução do experimento}

Utilizaram-se vasos de plástico com volume interno de 3,2 L que foram preenchidos com sílica (quartzo moído), e foi feita a semeadura do milho (cultivar AG-303), colocando-se 8 sementes por vaso, deixando-se 2 plantas, após o desbaste. Os vasos receberam a solução nutritiva correspondente a cada tratamento, a qual foi mantida nos vasos durante o dia e drenada durante a noite. A solução foi circulada através da sílica duas vezes por dia e trocada a cada dez dias. 


\subsubsection{Tratamentos, solução nutritiva e delineamento experimental}

Foram utilizados cinco níveis de cada micronutriente em $\mathrm{mg} \mathrm{L}^{-1}$, sendo para o $\mathrm{B}$ : $0 ; 0,25 ; 0,5 ; 1,0$ e 2,0 como ácido bórico $\left(\mathrm{H}_{3} \mathrm{BO}_{3}\right)$, para o $\mathrm{Cu}$ : 0 ; 0,$015 ; 0,020 ; 0,025$ e 0,030 como sulfato de cobre $\left(\mathrm{CuSO}_{4} \cdot 5 \mathrm{H}_{2} \mathrm{O}\right)$ e, para o $\mathrm{Zn}: 0$; 0,$05 ; 0,10 ; 0,20$ e 0,30 como sulfato de zinco $\left(\mathrm{ZnSO}_{4} \cdot 7 \mathrm{H}_{2} \mathrm{O}\right)$. As soluções foram preparadas a partir daquela proposta por Sarruge (1975), devidamente modificada para satisfazer o suprimento de todos os nutrientes exigidos pelo milho e, aplicar os tratamentos. Os níveis 0,$5 ; 0,02$ e $0,05 \mathrm{mg} \mathrm{L}^{-1} \mathrm{de} \mathrm{B}, \mathrm{Cu}$ e $\mathrm{Zn}$, respectivamente, correspondem ao do tratamento completo proposto por aquele autor. Após a realização de um experimento preliminar, nas mesmas condições do experimento definitivo, constatou-se que o nível de $0,05 \mathrm{mg} \mathrm{L}^{-1}$ de $\mathrm{Zn}$, foi insuficiente para o milho, pois as plantas apresentaram sintomas característicos de deficiência desse micronutriente. Portanto, resolveu-se aumentar esse nível para 0,10 $\mathrm{mg} \mathrm{L}^{-1} \mathrm{de} \mathrm{Zn}$.

Os tratamentos foram distribuídos num delineamento experimental inteiramente casualisado: 5 níveis, 3 micronutrientes (B, $\mathrm{Cu}$ e $\mathrm{Zn})$ e 4 repetições, perfazendo um total de 64 unidades experimentais. A planta teste foi o milho.

\subsubsection{Colheita, moagem e acondicionamento do material vegetal}

Após um período de 45 dias, foi colhida a parte aérea, que foi acondicionada em sacos de papel e seca em estufa com circulação forçada de ar à temperatura de $60{ }^{\circ} \mathrm{C}$ até obter-se massa constante. Uma vez determinada a massa, esse material foi moído, para se fazer a análise dos nutrientes nele contidos, segundo metodologia descrita por Sarruge \& Haag (1974). 


\subsection{Experimento 2}

\subsubsection{Amostragem e análise dos solos}

Amostras da camada arável de dois solos arenosos representativos do Município de Piracicaba, classificados como, Areia Quartzosa (AQ) e Podzólico Vermelho-Amarelo (PV), foram coletadas, secas ao ar, destorroadas, moídas e passadas em peneira com malha de $2 \mathrm{~mm}$ de abertura, sendo posteriormente submetidas à análise para a caracterização química.

As determinações de $\mathrm{P}, \mathrm{K}, \mathrm{Ca}, \mathrm{Mg}$, matéria orgânica, $\mathrm{pH}$ em $\mathrm{CaCl}_{2}$, acidez potencial $(\mathrm{H}+\mathrm{Al})$ e cálculos da soma de bases $(\mathrm{S})$, da capacidade de troca de cátions $(\mathrm{T})$ e da porcentagem de saturação por bases $(\mathrm{V} \%)$ foram realizados segundo metodologia descrita por Raij \& Quaggio (1983). Os micronutrientes $\mathrm{Cu}$, Fe, Mn e Zn, extraídos com DTPA-TEA conforme Camargo et al. (1986), e B pela água quente, segundo Bataglia \& Raij (1990) são apresentados na Tabela 2. A acidez dos solos foi corrigida para elevar a V\% a 70.

\subsubsection{Tratamentos}

Os tratamentos aplicados aos solos, após o término do período de incubação, foram constituídos por quatro níveis de cada micronutriente, em $\mathrm{mg}$ $\mathrm{dm}^{-3}$ de terra, sendo para o $\mathrm{Zn}, 0 ; 0,7 ; 1,4$ e 2,8, na forma de sulfato de zinco $\left(\mathrm{ZnSO}_{4} \cdot 7 \mathrm{H}_{2} \mathrm{O}\right)$, para $\mathrm{B}, 0,0,35 ; 0,70$ e 1,40 na forma de ácido bórico $\left(\mathrm{H}_{3} \mathrm{BO}_{3}\right)$ e para $\mathrm{Cu} 0 ; 0,5 ; 1,0$ e 2,0 na forma de sulfato de cobre $\left(\mathrm{CuSO}_{4} .5 \mathrm{H}_{2} \mathrm{O}\right)$. 
Tabela 2. Resultados das análises de terra das duas amostras de solos utilizadas no experimento.

\begin{tabular}{|c|c|c|c|}
\hline \multirow[t]{2}{*}{ Componente da análise } & \multicolumn{2}{|c|}{ Solo $^{1}$} & \multirow[t]{2}{*}{ Extratores } \\
\hline & AQ & PV & \\
\hline $\mathrm{P}\left(\mathrm{mg} \mathrm{dm}^{-3}\right)$ & 1,8 & 2,1 & Resina \\
\hline M.O. $\left(\mathrm{g} \mathrm{kg}^{-1}\right)$ & 11,8 & 15,3 & \\
\hline $\mathrm{pH}$ & 3,9 & 4,1 & $\mathrm{CaCl}_{2}$ \\
\hline $\mathrm{K}\left(\mathrm{mmol}_{\mathrm{c}} \mathrm{dm}^{-3}\right)$ & 1,9 & 0,4 & Resina \\
\hline $\mathrm{Ca}\left(\mathrm{mmol}_{\mathrm{c}} \mathrm{dm}^{-3}\right)$ & 9,1 & 2,5 & Resina \\
\hline $\mathrm{Mg}\left(\mathrm{mmol}_{\mathrm{c}} \mathrm{dm}^{-3}\right)$ & 2,0 & 0,8 & Resina \\
\hline $\mathrm{H}+\mathrm{Al}\left(\mathrm{mmol}_{\mathrm{c}} \mathrm{dm}^{-3}\right)$ & 86,1 & 35,2 & Tampão SMP \\
\hline $\mathrm{S}\left(\mathrm{mmol}_{\mathrm{c}} \mathrm{dm}^{-3}\right)$ & 13,1 & 3,8 & \\
\hline $\mathrm{T}\left(\mathrm{mmol}_{\mathrm{c}} \mathrm{dm}^{-3}\right)$ & 99,2 & 39,2 & \\
\hline $\mathrm{V}(\%)$ & 13 & 10 & \\
\hline $\mathrm{B}\left(\mathrm{mg} \mathrm{dm}^{-3}\right)$ & 0,10 & 0,08 & Água quente \\
\hline $\mathrm{Cu}\left(\mathrm{mg} \mathrm{dm}^{-3}\right)$ & 0,18 & 0,22 & DTPA-TEA ${ }^{2}$ \\
\hline $\mathrm{Fe}\left(\mathrm{mg} \mathrm{dm}^{-3}\right)$ & 27,3 & 61,2 & DTPA-TEA ${ }^{2}$ \\
\hline $\operatorname{Mn}\left(\mathrm{mg} \mathrm{dm}^{-3}\right)$ & 0,79 & 2,25 & DTPA-TEA ${ }^{2}$ \\
\hline $\mathrm{Zn}\left(\mathrm{mg} \mathrm{dm}^{-3}\right)$ & 0,16 & 0,29 & DTPA-TEA ${ }^{2}$ \\
\hline Areia $(\%)^{3}$ & 77 & 73 & \\
\hline Silte $(\%)^{3}$ & 11 & 6 & \\
\hline Argila $(\%)^{3}$ & 12 & 21 & \\
\hline
\end{tabular}

\subsubsection{Instalação e condução do experimento}

Os tratamentos foram distribuídos num delineamento experimental em blocos ao acaso, com 4 repetições: 4 × $3 \times 2$ (4 níveis, 3 micronutrientes, 2 solos), perfazendo um total de 96 unidades experimentais.

Utilizou-se vasos de plástico com capacidade para $3,2 \mathrm{dm}^{3}$ de solo. 9,3 e 3,9 g/vaso de calcário magnesiano (97\% de PRNT e $11 \%$ de S) para corrigir a acidez dos solos AQ e PV, respectivamente, e adicionar enxofre, foram bem 
homogeneizados com o solo contido em cada vaso e, incubado até atingir a V\% desejada, mantendo-se a umidade próxima da capacidade de campo. Após o período de incubação amostras de terra dos vasos foram coletadas e submetidas a uma nova análise química. Foi realizada a adubação de plantio com $10 \mathrm{mg} \mathrm{dm}^{-3}$ de $\mathrm{N}$ (uréia $45 \%$ de $\mathrm{N}$ ), $20 \mathrm{mg} \mathrm{dm}^{-3}$ de $\mathrm{P}$ (superfosfato simples $18 \%$ de $\mathrm{P}_{2} \mathrm{O}_{5}$ ) e $40 \mathrm{mg} \mathrm{dm}^{-3}$ de $\mathrm{K}$ (cloreto de potássio $60 \%$ de $\mathrm{K}_{2} \mathrm{O}$ ), segundo as recomendações do Boletim 100 do IAC (Raij et al., 1996). Os micronutrientes na forma de solução, foram aplicados aos vasos juntamente com a água de irrigação. Durante o desenvolvimento da cultura, foi realizada uma adubação de cobertura com $20 \mathrm{mg}$ $\mathrm{dm}^{-3} \mathrm{de} \mathrm{N}$ e $40 \mathrm{mg} \mathrm{dm}^{-3}$ de $\mathrm{K}$.

A semeadura do milho (Zea mays) híbrido, cultivar AG-303, cedida pelo Laboratório de Sementes da ESALQ/USP, foi efetuada, utilizando-se 8 sementes por vaso, deixando-se 2 plantas após o desbaste. Durante o desenvolvimento das plantas, o solo foi mantido próximo da capacidade de campo, através de irrigações diárias com água destilada.

O início do pendoamento (floração) ocorreu 60 dias após a germinação e o início da formação das espigas foi aos 70 dias e a colheita aos 80 dias.

\subsubsection{Diagnose foliar}

Aos 70 dias após a emergência, por ocasião da formação das espigas, no experimento 2, foi realizada uma amostragem, retirando-se a folha inteira abaixo da espiga superior (folha diagnóstica), incluída a nervura central, segundo a metodologia descrita por Malavolta et al. (1989). 


\subsubsection{Colheita, moagem e acondicionamento do material vegetal}

Depois de um período de 30, 70 e 80 dias após a emergência foram colhidas, a primeira planta (PAl), a folha diagnóstica (FD) e a segunda planta (PA2), respectivamente, acondicionadas em sacos de papel e secas em estufa com circulação forçada de ar à temperatura de $60^{\circ} \mathrm{C}$ até obter-se massa constante. Uma vez determinada a sua massa, esses materiais foram moídos, para se fazer a análise dos nutrientes neles contidos, segundo metodologia descrita por Sarruge \& Haag, (1974).

\subsubsection{Determinações no solo}

Antes da calagem, ao final do período de incubação e após a colheita das plantas de milho, colheu-se amostras da terra dos vasos e, os micronutrientes $\mathrm{Cu}, \mathrm{Zn}, \mathrm{Fe}$ e $\mathrm{Mn}$ foram extraídos, pelo método DTPA-TEA e somente após a colheita, esses micronutrientes foram extraídos pelos métodos DTPA-TEA, $\mathrm{HCl}$ 0,1M, Mehlich1 e Mehlich3. O B foi extraído com água quente, antes da calagem, ao final do período de incubação e após a colheita (Camargo et al.,1986; Bataglia \& Raij, 1990). A descrição das metodologias dos extratores vem a seguir:

DTPA-TEA (ácido dietileno-triamino-pentacético e trietanolamina, tamponado a pH 7,3) - $10 \mathrm{~cm}^{3}$ de TFSA com $20 \mathrm{~mL}$ da solução extratora foram agitados por 2 horas em agitador horizontal $(220 \mathrm{rpm})$. A suspensão foi filtrada em papel Whatman 42 e, no extrato obtido, determinou-se os nutrientes $\mathrm{Cu}$ e $\mathrm{Zn}$ por espectrofotometria de absorção atômica (Camargo et al.,1986). 
HCI 0,1M $-5 \mathrm{~cm}^{3}$ de TFSA com $25 \mathrm{~mL}$ da solução extratora foram agitados por 30 minutos, a seguir procedeu-se como para o extrator DTPA-TEA (EMBRAPA, 1997).

Mehlich1 - $5 \mathrm{~cm}^{3}$ de TFSA com $50 \mathrm{~mL}$ da solução extratora $(\mathrm{HCl} 0,05 \mathrm{~N}$ $+\mathrm{H}_{2} \mathrm{SO}_{4} 0,025 \mathrm{~N}$ ) foram agitados por 5 minutos, a seguir procedeu-se como para o extrator DTPA-TEA (EMBRAPA, 1997).

Mehlich3 $-5 \mathrm{~cm}^{3}$ de TFSA com $50 \mathrm{~mL}$ da solução extratora $\left(\mathrm{CH}_{3} \mathrm{COOH}\right.$ $0,2 \mathrm{~N} ; \mathrm{NH}_{4} \mathrm{NO}_{3} 0,25 \mathrm{~N} ; \mathrm{NH}_{4} \mathrm{~F} 0,015 \mathrm{~N} ; \mathrm{HNO}_{3} 0,013 \mathrm{~N}$ e EDTA $0,001 \mathrm{M}$ ), foram agitados por 5 minutos, a seguir procedeu-se como para o extrator DTPA-TEA (Mehlich, 1984).

Água quente $-10 \mathrm{~cm}^{3}$ de TFSA com $20 \mathrm{~mL}$ da solução de cloreto de bário $\left(\mathrm{BaCl}_{2} \cdot 2 \mathrm{H}_{2} \mathrm{O}\right)$ a $0,125 \%$, foram aquecidos em forno de microondas com prateleira giratória, por 4 minutos na potência de 700 watts. A suspensão foi filtrada em papel Whatman 42 e, no extrato obtido, após adicionar-se $2 \mathrm{~mL}$ da solução de azometina-H a $0,9 \%$, procedeu-se às leituras em espectrofotômetro com filtro azul (420 nm) (Bataglia \& Raij, 1990).

\subsection{Determinações no material vegetal (Experimentos 1 e 2)}

\subsubsection{Produção de material vegetal seco}

Após a secagem em estufa, foi determinada a produção de material vegetal seco da parte aérea das plantas de milho, através de pesagem em balança analítica. 


\subsubsection{Composição mineral}

A determinação das concentrações de nitrogênio, fósforo, potássio, cálcio, magnésio, enxofre, boro, cobre, ferro, manganês e zinco da parte aérea foi efetuada conforme a metodologia descrita por Sarruge \& Haag, (1974).

\subsection{Avaliação dos resultados}

Os resultados tanto do experimento 1 , quanto do experimento 2 foram avaliados através dos seguintes parâmetros: produção de material vegetal seco da parte aérea das plantas de milho, concentração dos nutrientes e nutrientes absorvidos ou acumulados.

As análises estatísticas dos resultados de produção de material vegetal seco e concentração de nutrientes na parte aérea, foram realizadas obedecendo-se aos modelos matemáticos próprios para os delineamentos propostos (experimento 1: inteiramente casualizado, experimento 2: blocos ao acaso), realizando teste de Tukey a $1 \%$ de probabilidade para a comparação entre as médias e a análise de regressão para relacionar a concentração de nutrientes do solo com a produção de material vegetal seco e os nutrientes absorvidos pela parte aérea do milho. Foi obtido também o nível crítico, correspondente a $90 \%$ da produção máxima, derivando-se as equações obtidas na análise de regressão, para a produção de material vegetal seco, cuja relação com as doses de nutrientes aplicadas aos solos foi significativa. 


\section{RESULTADOS E DISCUSSĀO}

\subsection{Experimento em solução nutritiva}

\subsubsection{Boro}

As análises de variância dos resultados mostraram que os níveis de boro influíram significativamente $(\mathrm{P}<0,01)$ na concentração desse nutriente na parte aérea do milho, porém o mesmo não aconteceu com a produção de material vegetal seco (Tabela 3), onde não houve diferenças em função dos níveis aplicados na solução nutritiva. Observa-se que a dose $2,0 \mathrm{mg} \mathrm{L}^{-1}$ foi a que proporcionou a maior concentração de $\mathrm{B}$, que não diferiu da dose 1,0 e esta, por sua vez, não diferiu das doses 0,5 e 0,25. Como era de esperar, a aplicação de $B$ não influenciou as concentrações de $\mathrm{Cu}$ e $\mathrm{Zn}$ na parte aérea das plantas de milho.

A Figura 1 relaciona $\mathrm{o}$ B adicionado na solução nutritiva com a concentração de B no material vegetal seco da parte aérea das plantas de milho, mostrando um efeito quadrático altamente significativo.

Por outro lado, a ausência de $\mathrm{B}$ na solução (dose $0 \mathrm{mg} \mathrm{dm}^{-3}$ ) não provocou o aparecimento de sintomas de deficiência desse nutriente nas plantas de milho. 
Tabela 3. Material vegetal seco e concentração de nutrientes, em função das doses de B (Médias de quatro repetições).

\begin{tabular}{ccccc}
\hline $\begin{array}{c}\text { Dose de B } \\
\left(\mathrm{mg} \mathrm{L}^{-1}\right)\end{array}$ & MS & B & Cu & Zn \\
\hline & (g/vaso) & $-\cdots, 0-\cdots \mathrm{c}^{-1}$ & $3,2 \mathrm{a}$ & $6,0 \mathrm{a}$ \\
0,00 & $29,6 \mathrm{a}$ & $9,0-\mathrm{c}^{-}$ & $3,0 \mathrm{a}$ & $7,5 \mathrm{a}$ \\
0,25 & $27,3 \mathrm{a}$ & $22,5 \mathrm{~b} \mathrm{c}$ & $2,2 \mathrm{a}$ & $5,8 \mathrm{a}$ \\
0,50 & $28,9 \mathrm{a}$ & $23,5 \mathrm{~b} \mathrm{c}$ & $1,2 \mathrm{a}$ & $7,5 \mathrm{a}$ \\
1,00 & $28,6 \mathrm{a}$ & $48,8 \mathrm{a} \mathrm{b}$ & $2,0 \mathrm{a}$ & $7,0 \mathrm{a}$ \\
2,00 & $27,8 \mathrm{a}$ & $64,8 \mathrm{a}$ & 4,6 & 3,1 \\
\hline DMS & 15,9 & 35,9 & 66,9 & 15,6 \\
CV \% & 19,2 & 36,5 & 6
\end{tabular}

Médias seguidas pela mesma letra não diferem significativamente entre si ao nível de $1 \%$, pelo teste de Tukey.

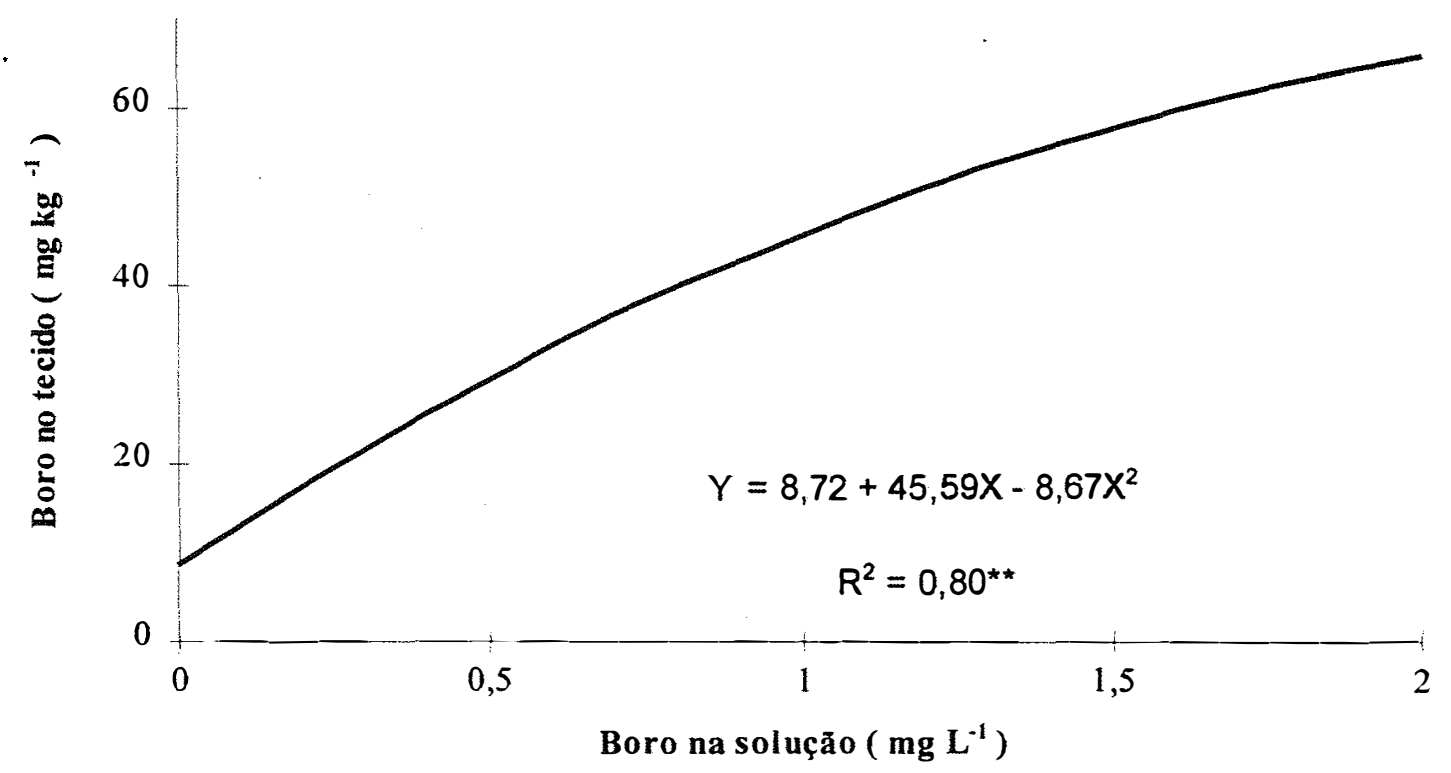

Figura 1. Relação entre a concentração de B na parte aérea das plantas de milho e as doses de $\mathrm{B}$ na solução nutritiva. 


\subsubsection{Cobre}

As análises de variância dos resultados de produção de material vegetal seco e concentração de cobre na parte aérea das plantas de milho, mostraram que não houve resposta significativa do milho às doses de $\mathrm{Cu}$ utilizadas (Tabela 4).

Tabela 4. Material vegetal seco (MS) e concentração de nutrientes, em função das doses de $\mathrm{Cu}$ (Médias de quatro repetições).

\begin{tabular}{|c|c|c|c|c|}
\hline $\begin{array}{c}\text { Dose de } \mathrm{Cu} \\
\left(\mathrm{mg} \mathrm{L}^{-1}\right)\end{array}$ & MS & $\bar{B}$ & $\mathrm{Cu}$ & $\mathrm{Zn}$ \\
\hline & (g/vaso) & $\cdots$ & $\mathrm{mg} \mathrm{kg}$ & --- \\
\hline 0,000 & $28,4 \mathrm{a}$ & $27,8 \mathrm{a}$ & $3,0 \mathrm{a}$ & $5,2 \mathrm{a}$ \\
\hline 0,015 & $29,9 \mathrm{a}$ & $20,5 \mathrm{a}$ & $2,8 \mathrm{a}$ & $9,0 \mathrm{a}$ \\
\hline 0,020 & $28,9 \mathrm{a}$ & $23,5 \mathrm{a}$ & $2,2 \mathrm{a}$ & $5,8 \mathrm{a}$ \\
\hline 0,025 & $28,1 \mathrm{a}$ & $19,8 \mathrm{a}$ & $4,0 \mathrm{a}$ & $6,5 \mathrm{a}$ \\
\hline 0,030 & 29,3 a & $28,0 \mathrm{a}$ & $3,0 \mathrm{a}$ & $5,5 \mathrm{a}$ \\
\hline DMS & 12,6 & 19,0 & 4,5 & 5,8 \\
\hline CV\% & 15,0 & 27,2 & 51,2 & 31,1 \\
\hline
\end{tabular}

Médias seguidas pela mesma letra em cada coluna não diferem significativamente entre si ao nível de $1 \%$, pelo teste de Tukey.

\subsubsection{Zinco}

As análises de variância dos resultados mostraram que as doses de zinco influíram significativamente $(\mathrm{P}<0,01)$ na produção de material vegetal seco e na concentração desse nutriente na parte aérea das plantas de milho (Tabela 5). Observou-se que a aplicação desse nutriente na solução propiciou um aumento em relação à testemunha, sendo que a dose $0,3 \mathrm{mg} \mathrm{L}^{-1}$ de $\mathrm{Zn}$ propiciou a maior produção de material vegetal seco e a maior concentração no tecido. A dose 0,1 foi suficiente para alcançar a máxima produção de material vegetal seco que não diferiu estatisticamente da dose máxima $(0,3)$ e nem da intermediária $(0,2)$. Por 
outro lado, observou-se também efeito significativo $(\mathrm{P}<0,01)$ das doses de $\mathrm{Zn}$ na concentração de $\mathrm{Zn}$ no tecido analisado, a máxima concentração de $\mathrm{Zn}$ foi alcançada com a maior dose $(0,3)$. As doses de $\mathrm{Zn}$ aplicadas na solução nutritiva não influenciaram as concentrações de $\mathrm{B}$ e $\mathrm{Cu}$ no tecido.

Tabela 5. Material vegetal seco (MS) e concentração de nutrientes, em função das doses de $\mathrm{Zn}$ (Médias de quatro repetições).

\begin{tabular}{ccccc}
\hline $\begin{array}{c}\text { Dose de } \mathrm{Zn} \\
\left(\mathrm{mg} \mathrm{L}^{-1}\right)\end{array}$ & MS & $\mathrm{B}$ & $\mathrm{Cu}$ & $\mathrm{Zn}$ \\
\hline & (g/vaso) & $-\cdots, 0-\cdots \mathrm{a}$ & $3,8 \mathrm{a}$ & $3,8 \mathrm{~d}$ \\
0,00 & $18,8 \mathrm{~b}$ & $31,0 \mathrm{c}$ & $6,0 \mathrm{c}$ \\
0,05 & $28,3 \mathrm{~b}$ & $23,8 \mathrm{a}$ & $3,8 \mathrm{a}$ & $7,9 \mathrm{~b}$ \\
0,10 & $28,9 \mathrm{a} \mathrm{b}$ & $23,5 \mathrm{a}$ & $2,2 \mathrm{a}$ & $8,5 \mathrm{~b}$ \\
0,20 & $34,7 \mathrm{a}$ & $26,0 \mathrm{a}$ & $8,7 \mathrm{a}$ & $10,2 \mathrm{a}$ \\
0,30 & $40,0 \mathrm{a}$ & $26,5 \mathrm{a}$ & $2,8 \mathrm{a}$ & 1,7 \\
\hline DMS & 14,4 & 23,4 & 10,9 & 8,1 \\
CV \% & 16,4 & 30,6 & 88,2 & \\
\hline
\end{tabular}

Médias seguidas pela mesma letra em cada coluna não diferem significativamente entre si ao nível de $1 \%$, pelo teste de Tukey.

As Figuras 2 e 3, mostram respectivamente, os efeitos quadráticos altamente significativos das doses de $\mathrm{Zn}$ sobre a produção de material vegetal seco $\left(\mathrm{R}^{2}=0,73\right)$ e quantidade do nutriente absorvida $\left(\mathrm{R}^{2}=0,92\right)$ pela parte aérea das plantas de milho. Derivando-se a equação da Figura 2, encontrou-se que a dose máxima correspondente a $90 \%$ da produção máxima de material vegetal seco, foi igual a $0,70 \mathrm{mg} \mathrm{L}^{-1}$. 


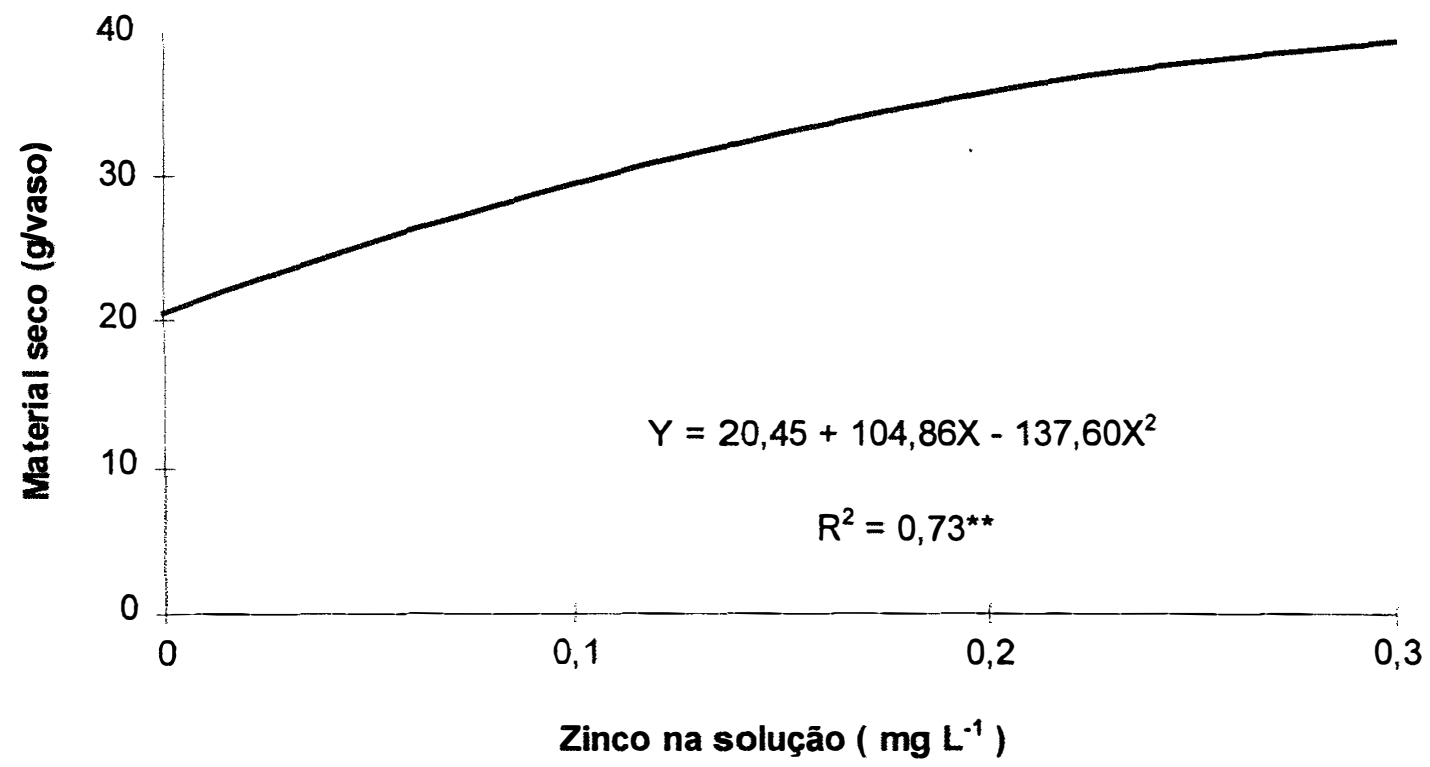

Figura 2. Relação entre a produção de material vegetal seco na parte aérea das plantas de milho, e as doses de $\mathrm{Zn}$ na solução nutritiva.

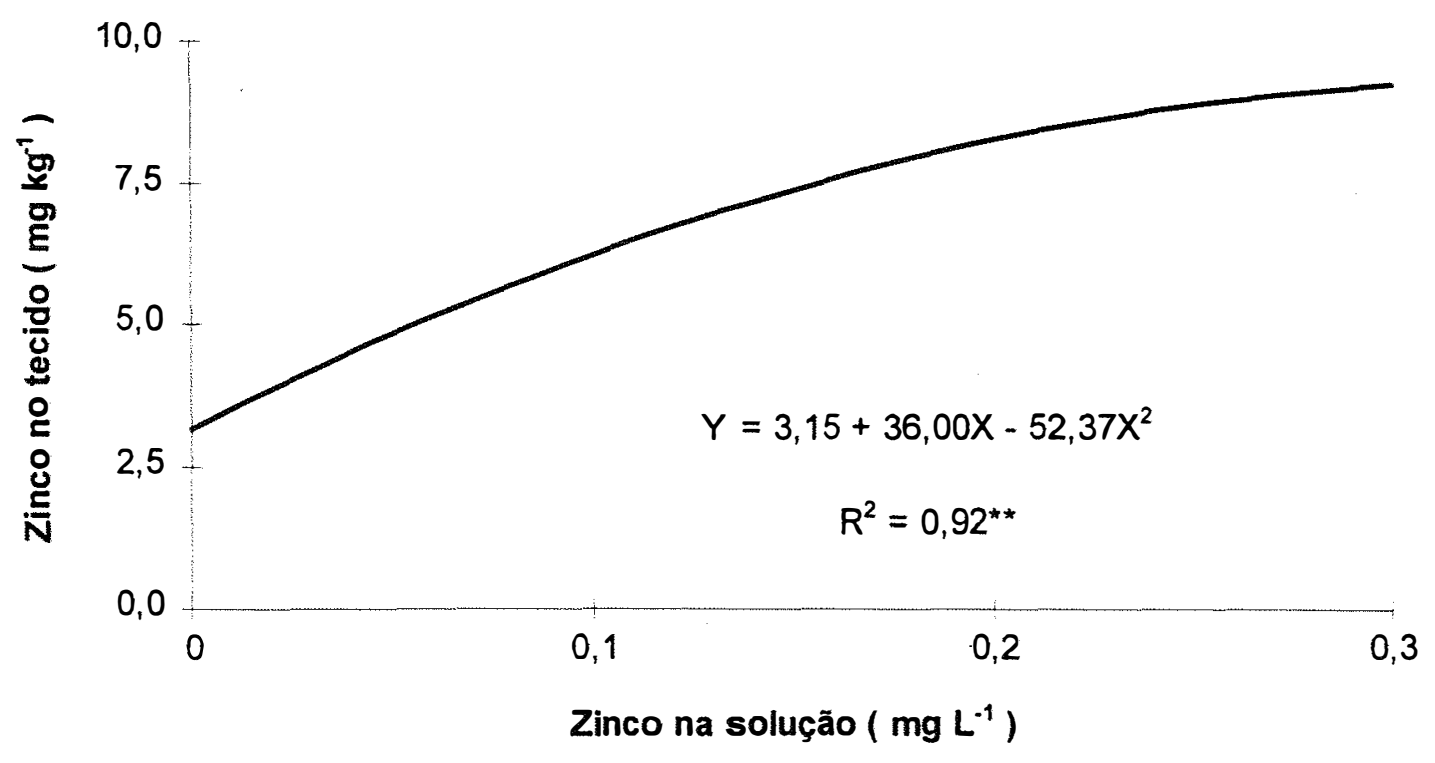

Figura 3. Relação entre a concentração de $\mathrm{Zn}$ na parte aérea das plantas de milho, e as doses de $\mathrm{Zn}$ na solução nutritiva. 
A Figura 4 (a) apresenta o efeito das doses de zinco no crescimento das plantas de milho. Observa-se claramente que esse efeito foi quadrático, o que veio a ser confirmado pela análise estatística da produção de material vegetal seco, após o corte da parte aérea das plantas. A Figura 4 (b) apresenta os sintomas típicos de deficiência de $\mathrm{Zn}$, no tratamento onde não se aplicou esse micronutriente (dose $0 \mathrm{mg} \mathrm{L}^{-1}$ ), tais como, folhas pequenas, com manchas amareladas e encurtamento dos internódios. Apresenta ainda uma diferença de crescimento marcante entre o tratamento sem a adição de $\mathrm{Zn}$, comparando-se com o tratamento completo, em que foi adicionado $0,1 \cdot \mathrm{mg} \mathrm{L}^{-1}$ de $\mathrm{Zn}$ na solução nutritiva.

\subsection{Experimento em solos}

\subsubsection{Análise dos solos após a calagem}

Após a calagem, para a correção da acidez dos solos AQ e PV, ocorreram modificações nas características químicas, as quais podem ser observadas na Tabela 6.

Ao se comparar estes resultados com os da Tabela 2, pode-se observar que houve aumento do $\mathrm{pH}$ em ambos os solos e a V pretendida (70 \%) foi alcançada no solo PV (68 \%), enquanto que no solo AQ, a $V$ foi maior do que a pretendida $(83 \%)$. A dose de calcário, o tipo e o período de incubação foram suficientes no solo $\mathrm{AQ}$, já no solo PV provavelmente a dose de corretivo poderia ser menor. Como era de se esperar, as concentrações de Ca e $\mathrm{Mg}$ aumentaram até níveis considerados altos e médios para o desenvolvimento do milho, nos solos $\mathrm{AQ}$ e $\mathrm{PV}$, respectivamente, provocando aumentos da soma de bases (nível alto para $\mathrm{AQ}$ e médio para $\mathrm{PV}$ ) e diminuição da capacidade de troca de cátions calculada (nível alto no solo AQ e baixo no solo PV). As concentrações de P e de 


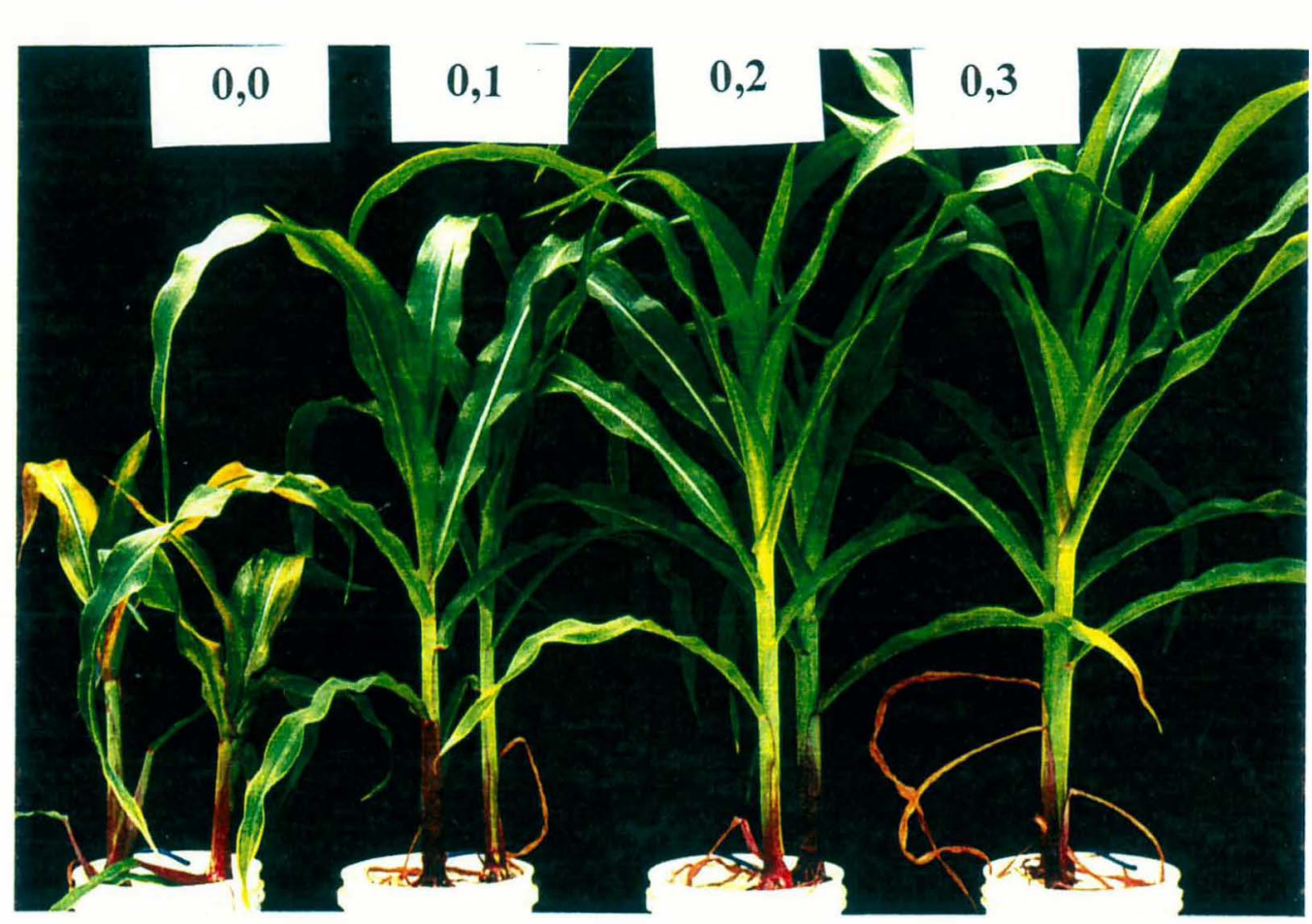

( a )

(b)

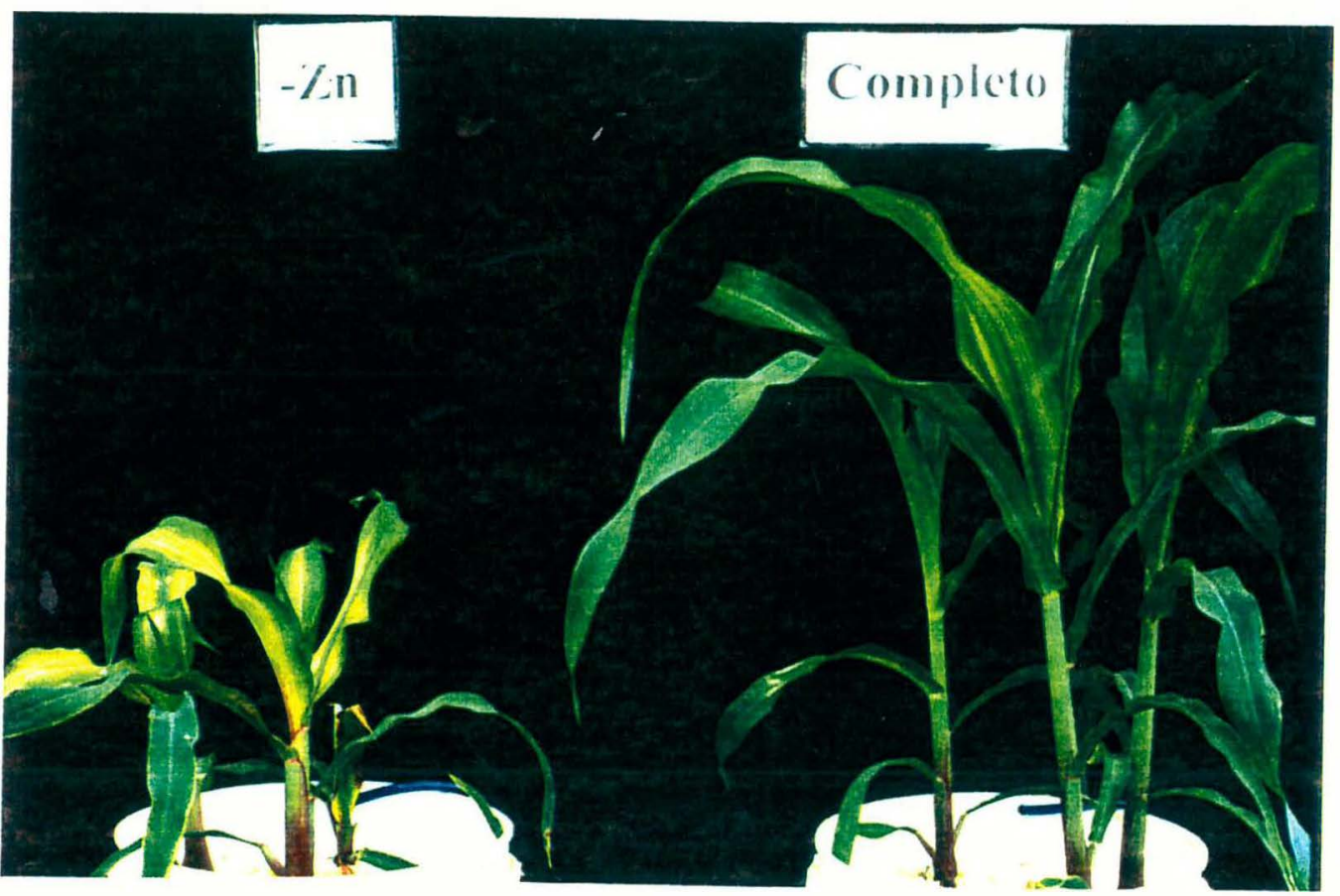

Figura 4. Visualização do crescimento das plantas de milho em função das doses de Zn (a), Sintomas de deficiência de Zn e o tratamento completo (b). 
Tabela 6. Resultado das análises de terra após a calagem, para as duas amostras de solo utilizadas no experimento.

\begin{tabular}{lccl}
\hline Componente da análise & \multicolumn{2}{c}{ Solo } & Extratores \\
\cline { 2 - 3 } & AQ & PV & \\
\hline $\mathrm{P}\left(\mathrm{mg} \mathrm{dm}^{-3}\right)$ & 5,5 & 5,2 & Resina \\
$\mathrm{M} . \mathrm{O}\left(\mathrm{g} \mathrm{kg}^{-1}\right)$ & 12 & 13 & \\
$\mathrm{pH}$ & 5,0 & 4,5 & $\mathrm{CaCl}_{2}$ \\
$\mathrm{~K}\left(\mathrm{mmol}_{\mathrm{c}} \mathrm{dm}^{-3}\right)$ & 1,9 & 0,5 & Resina \\
$\mathrm{Ca}\left(\mathrm{mmol}_{\mathrm{c}} \mathrm{dm}^{-3}\right)$ & 36,0 & 15,0 & Resina \\
$\mathrm{Mg}\left(\mathrm{mmol}_{\mathrm{c} \mathrm{dm}} \mathrm{dm}^{-3}\right)$ & 25,0 & 8,0 & Resina \\
$\mathrm{H}+\mathrm{Al}\left(\mathrm{mmol}_{\mathrm{c}} \mathrm{dm}^{-3}\right)$ & 13 & 13 & Tampão SMP \\
$\mathrm{S}\left(\mathrm{mmol}_{\mathrm{c}} \mathrm{dm}^{-3}\right)$ & 64 & 27 & \\
$\left.\mathrm{~T}\left(\mathrm{mmol}_{\mathrm{c} \mathrm{dm}}\right)^{-3}\right)$ & 78 & 40 & \\
$\mathrm{~V}(\%)$ & 68 & \\
$\mathrm{~B}\left(\mathrm{mg} \mathrm{dm}^{-3}\right)$ & 83 & 0,06 & Água quente \\
$\mathrm{Cu}\left(\mathrm{mg} \mathrm{dm}^{-3}\right)$ & 0,09 & 0,29 & DTPA-TEA \\
$\mathrm{Fe}\left(\mathrm{mg} \mathrm{dm}^{-3}\right)$ & 0,16 & 13,6 & DTPA-TEA \\
$\mathrm{Mn}\left(\mathrm{mg} \mathrm{dm}^{-3}\right)$ & 34,6 & 2,4 & DTPA-TEA \\
$\mathrm{Zn}\left(\mathrm{mg} \mathrm{dm}^{-3}\right)$ & 3,8 & 0,54 & DTPA-TEA \\
\hline
\end{tabular}

Zn também aumentaram em ambos os solos ( $\mathrm{Zn}$ nível baixo no solo $\mathrm{AQ}$ e médio no solo PV, e P nível baixo em ambos os solos). Esses aumentos ocorreram provavelmente devido à calagem ter aumentado o $\mathrm{pH}$, favorecendo assim a sua liberação para a solução do solo, no caso do $\mathrm{P}$; enquanto no caso do $\mathrm{Zn}$, seguramente esse nutriente estava contido nas impurezas do calcário. Observa-se que os valores de $\mathrm{pH}$ em ambos os solos estão abaixo do intervalo de 5,0 a 8,0 ( $<5,0$ no solo PV) e no limite (5,0 no solo AQ), que Lindsay (1983) considerou como o intervalo onde ocorre um decréscimo na solubilidade dos micronutrientes catiônicos, entre eles o $\mathrm{Zn}$ e o $\mathrm{Cu}$, estudados neste trabalho. Segundo Bataglia (1988) a diminuição da disponibilidade de $\mathrm{B}, \mathrm{Cu}$ e $\mathrm{Zn}$ pela calagem ocorre, mas, só é critica, quando o pH eleva-se muito acima de 6,0. 


\subsubsection{Boro}

\subsubsection{No solo}

As concentrações de $\mathrm{B}$ determinadas inicialmente nos dois tipos de solo (Areia Quartzosa-AQ e Podzólico Vermelho Amarelo-PV) foram 0,10 e 0,08 $\mathrm{mg} \mathrm{dm}{ }^{-3}$, respectivamente. Após a aplicação do nutriente em função dos tratamentos, ocorreram modificações, como era de se esperar, as quais podem ser observadas na Tabela 7.

Os resultados mostram que as doses de $\mathrm{B}$ proporciónaram aumentos estatisticamente significativos nas concentrações desse nutriente. A concentração de $\mathrm{B}$ detectada na análise inicial foi mais elevada no solo AQ do que no solo PV. As concentrações do nutriente determinadas nos dois tipos de solo estão dentro dos limites citados por Fleming (1980) e Malavolta (1987).

Tabela 7. Concentrações de B $\left(\mathrm{mg} \mathrm{dm}^{-3}\right)$ nos solos AQ e PV em função das doses aplicadas.

\begin{tabular}{ccc}
\hline $\begin{array}{c}\text { Dose de B } \\
\left(\mathrm{mg} \mathrm{dm}^{-3}\right)\end{array}$ & \multicolumn{2}{c}{ Solo } \\
\cline { 2 - 3 } & AQ & PV \\
\hline 0,00 & $0,09 \mathrm{~d}$ & $0,06 \mathrm{~b}$ \\
0,35 & $0,28 \mathrm{c}$ & $0,08 \mathrm{~b}$ \\
0,70 & $0,45 \mathrm{~b}$ & $0,14 \mathrm{~b}$ \\
1,40 & $0,98 \mathrm{a}$ & $0,29 \mathrm{a}$ \\
\hline Médias & $0,45 \mathrm{~A}$ & $0,57 \mathrm{~A}$ \\
\hline CV\% & 17,10 & 31,20 \\
DMS & 0,15 & 0,14 \\
\hline
\end{tabular}

Médias seguidas pela mesma letra maiúscula na horizontal ou minúscula na vertical não diferem significativamente entre si, ao nível de $1 \%$, pelo teste de Tukey. 


\subsubsection{Na parte aérea da planta}

\subsection{Na folha diagnóstica}

$\mathrm{Da}$ análise da folha diagnóstica (FD), primeira folha abaixo da inserção das espigas de milho, também conhecida como folha bandeira, encontrou-se as concentrações de B apresentadas na Tabela 8, em função do tipo de solo e das doses aplicadas aos solos, respectivamente. Observa-se que, não houve diferenças significativas tanto entre solos quanto entre doses .

Tabela 8. Concentrações de B na folha diagnóstica, em função do tipo de solo e das doses de B aplicadas (Médias de quatro repetições).

\begin{tabular}{|c|c|c|}
\hline \multirow{2}{*}{$\begin{array}{l}\text { Dose de B } \\
\left(\mathrm{mg} \mathrm{dm}^{-3}\right)\end{array}$} & \multicolumn{2}{|c|}{ Solo } \\
\hline & $\overline{\mathrm{AQ}}$ & PV \\
\hline 000 & 477 a & $7859 \mathrm{~A}$ \\
\hline 0,35 & 77,0 a A & 90,0 a A \\
\hline 0,70 & $100.0 \mathrm{a} \mathrm{A}$ & $105,5 \mathrm{a} \mathrm{A}$ \\
\hline 1,40 & 94,0 a $A$ & 91,5 a $A$ \\
\hline Médias & $71,7 \mathrm{~A}$ & $91,3 \mathrm{~A}$ \\
\hline CV\% & 22,1 & 18,9 \\
\hline DMS & 52,4 & 51,4 \\
\hline
\end{tabular}

Médias seguidas pela mesma letra maiúscula na horizontal ou minúscula na vertical não diferem significativamente entre si, ao nível de $1 \%$, pelo teste de Tukey.

\subsection{Na planta colhida 30 dias após a emergência}

A análise das concentrações de $\mathrm{B}$ no material vegetal seco das plantas colhidas aos 30 dias após a emergência (MSPA1), em função do tipo de solo e das doses de B aplicadas, encontram-se na Tabela 9. 
Tabela 9. Material vegetal seco da parte aérea das plantas de milho colhidas aos 30 dias após a emergência (MSPA1) e concentração de B, em função das doses de $\mathrm{B}$ e do tipo de solo (Médias de quatro repetições).

\begin{tabular}{|c|c|c|c|c|}
\hline \multirow{2}{*}{$\begin{array}{l}\text { Dose de B } \\
\left(\mathrm{mg} \mathrm{dm}^{-3}\right)\end{array}$} & \multicolumn{2}{|c|}{ MSPA1 } & \multicolumn{2}{|c|}{ Concentração de B } \\
\hline & AQ & PV & $\overline{\mathrm{AQ}}$ & PV \\
\hline & & & & \\
\hline 0,00 & 5,5 a $A$ & 3,5 a B & 15,0 a $\mathrm{A}$ & 14,5 a $\mathrm{A}$ \\
\hline 0,35 & 5,7 a $\mathrm{A}$ & 2,7 a B & 14,8 a $\mathrm{A}$ & 18,0 a $A$ \\
\hline 0,70 & 6,4 a A & 2,4 a B & 16,8 a $A$ & 21,5 a $\mathrm{A}$ \\
\hline 1,40 & 5,9 a A & 2,6 a B & 21,8 a A & 24,0 a $\mathrm{A}$ \\
\hline Médias & $5,9 \mathrm{~A}$ & $2,8 \mathrm{~B}$ & $17,1 \mathrm{~A}$ & $19,5 \mathrm{~A}$ \\
\hline $\mathrm{CV} \%$ & 11,1 & 29,7 & 16,5 & 38,2 \\
\hline DMS & 3,0 & 2,5 & 8,4 & 22,2 \\
\hline
\end{tabular}

Médias seguidas pela mesma letra maiúscula na horizontal ou minúscula na vertical não diferem significativamente entre si, ao nível de $1 \%$, pelo teste de Tukey.

Observa-se que houve diferença apenas na produção de material vegetal seco entre os solos, sendo maior no solo $A Q$, provavelmente devido às concentrações de B serem superiores neste solo para todas as doses aplicadas (Tabela 7).

\subsection{Na planta colhida ao final do experimento}

A análise do material vegetal seco produzido pelas plantas de milho colhidas ao final do experimento, após a emissão das espigas (MSPA2), da concentração de $\mathrm{B}$ e do $\mathrm{B}$ absorvido, em função do tipo de solo e das doses de B, encontram-se na Tabela 10. 
Tabela 10. Material vegetal seco da parte aérea das plantas de milho após a emissão das espigas (MSPA2) concentração de B e quantidade de B absorvida, em função do tipo de solo e das doses de B (Médias de quatro repetições).

\begin{tabular}{|c|c|c|c|c|c|c|}
\hline \multirow{2}{*}{$\begin{array}{l}\text { Dose de B } \\
\left(\mathrm{mg} \mathrm{dm}^{-3}\right)\end{array}$} & \multicolumn{2}{|c|}{ MSPA2 } & \multicolumn{2}{|c|}{ Concentração de B } & \multicolumn{2}{|c|}{ Absorção de B } \\
\hline & $\mathrm{AQ}$ & PV & AQ & PV & $\overline{\mathrm{AQ}}$ & PV \\
\hline & \multicolumn{2}{|c|}{-g/vaso- } & \multicolumn{2}{|c|}{ mg kg ${ }^{-1}$} & \multicolumn{2}{|c|}{---mg/vaso------ } \\
\hline 0,00 & $31,4 \mathrm{aA}$ & $23,3 \mathrm{aA}$ & $9,2 \mathrm{aA}$ & $7,0 \mathrm{aA}$ & $0,3 \mathrm{aA}$ & $0,2 \mathrm{aA}$ \\
\hline 0,35 & $29,0 \mathrm{aA}$ & 29,8 aA & $9,0 \mathrm{aA}$ & $9,0 \mathrm{aA}$ & $0,2 \mathrm{aA}$ & $0,2 \mathrm{aA}$ \\
\hline 0,70 & $30,4 \mathrm{aA}$ & $24,5 \mathrm{aA}$ & $13,2 \mathrm{aA}$ & $14,5 \mathrm{aA}$ & $0,4 \mathrm{aA}$ & $0,4 \mathrm{aA}$ \\
\hline 1,40 & $32,6 \mathrm{aA}$ & 25,4 aA & $18,2 \mathrm{aA}$ & $16,2 \mathrm{aA}$ & $0,6 \mathrm{aA}$ & $0,4 \mathrm{aA}$ \\
\hline Médias & $30,8 \mathrm{~A}$ & $25,8 \mathrm{~A}$ & $12,4 \mathrm{~A}$ & $11,7 \mathrm{~A}$ & $0,4 \mathrm{~A}$ & $0,3 \mathrm{~A}$ \\
\hline CV\% & 16,3 & 22,5 & 47,3 & 46,6 & 43,5 & 47,3 \\
\hline DMS & 14,9 & 17,3 & 17,5 & 16,2 & 0,5 & 0,4 \\
\hline
\end{tabular}

Médias seguidas pela mesma letra maiúscula na horizontal ou minúscula na vertical não diferem significativamente entre si, ao nível de $1 \%$, pelo teste de Tukey.

O material vegetal seco da parte aérea das plantas de milho foi estatisticamente semelhante tanto para a testemunha (dose $0 \mathrm{mg} \mathrm{dm}^{-3}$ ) quanto para a dose máxima de $\mathrm{B}$ (dose $1,4 \mathrm{mg} \mathrm{dm}^{-3}$ ). Embora haja uma tendência de aumento da concentração de $\mathrm{B}$ e do $\mathrm{B}$ absorvido pela parte aérea das plantas de milho, em função do tipo de solo e das doses de B aplicadas, não foram significativos estatisticamente $(\mathrm{P}<0,01)$.

Vários trabalhos encontrados na literatura, relatam que a deficiência ou a omissão de B no substrato não afeta a produção de material vegetal seco da parte aérea do milho. Ainda tem-se dúvidas a respeito do nível crítico de $\mathrm{B}$ para solos sob vegetação de Cerrado. Abreu et al. (1987) afirmaram que solos com concentrações de $\mathrm{B}$, extraídas com água quente, menores que $0,1\left(\mathrm{mg} \mathrm{dm}^{-3}\right)$ poderão ser deficientes nesse nutriente. A concentração de $B$ na dose $0 \mathrm{mg} \mathrm{dm}^{-3}$, nos solos estudados está abaixo desse nível (Tabela 7), sugerindo que os mesmos responderiam à adição desse nutriente, o que não aconteceu, pois o milho não respondeu ao $\mathrm{B}$ adicionado em nenhum dos solos. 
Gallo et al. (1965); Britto et al. (1971); Galrão \& Mesquita Filho (1981); Galrão et al. (1984); Abreu et al. (1987); Galrão (1988) estudando o efeito do $\mathrm{B}$, constataram que o milho não respondeu à aplicação desse nutriente.

\subsubsection{Cobre}

\subsubsection{No solo}

As concentrações de cobre, determinadas na análise inicial nos dois tipos de solo $\mathrm{AQ}$ e $\mathrm{PV}$, foram de 0,18 e $0,22 \mathrm{mg} \mathrm{kg}^{-1}$, respectivamente, as quais são consideradas como níveis baixos (Viets Junior \& Lindsay, 1983; Abreu, 1995), tiveram aumentos significativos em função das doses de $\mathrm{Cu}$ aplicadas e esses resultados podem ser observados na Tabela 11.

Tabela 11. Concentrações de $\mathrm{Cu}$ nos solos $\mathrm{AQ}$ e $\mathrm{PV}$ em função das doses aplicadas.

\begin{tabular}{lcc}
\hline $\begin{array}{l}\text { Dose de } \mathrm{Cu} \\
\left(\mathrm{mg} \mathrm{dm}^{-3}\right)\end{array}$ & \multicolumn{2}{c}{ Solo } \\
\cline { 2 - 3 } 0,0 & $0,19 \mathrm{~b}$ & PV \\
\hline 0,5 & $0,42 \mathrm{a}$ & $0,22 \mathrm{~b}$ \\
1,0 & $0,48 \mathrm{a}$ & $0,62 \mathrm{ab}$ \\
2,0 & $0,50 \mathrm{a}$ & $0,88 \mathrm{ab}$ \\
Médias & $0,40 \mathrm{~B}$ & $1,03 \mathrm{a}$ \\
\hline CV\% & 8,11 & $0,69 \mathrm{~A}$ \\
DMS & 0,09 & 48,10 \\
\hline
\end{tabular}

Médias seguidas pela mesma letra maiúscula na horizontal ou minúscula na vertical não diferem significativamente entre si ao nível de $1 \%$, pelo teste de Tukey. 
Observa-se que, em ambos os solos, ocorreram aumentos significativos do nutriente em função das doses aplicadas. Verifica-se também que no solo $\mathrm{PV}$, as concentrações são maiores que no solo $\mathrm{AQ}$ em todos os tratamentos. No solo $\mathrm{AQ}$ nas doses 0,$5 ; 1,0$ e $2,0 \mathrm{mg} \mathrm{dm}^{-3}$ a concentração de $\mathrm{Cu}$ foi significativamente $(\mathrm{P}<0,01)$ mais alta do que na dose zero. No solo $\mathrm{PV}$ a dose $2,0 \mathrm{mg} \mathrm{dm}^{-3}$ propiciou a maior concentração de $\mathrm{Cu}$, porém não diferente estatisticamente das doses 0,5 e 1,0 e diferindo da dose zero, em que a concentração de $\mathrm{Cu}$ foi menor.

\subsubsection{Na parte aérea da planta}

\subsection{Na folha diagnóstica}

As concentrações de $\mathrm{Cu}$ na folha diagnóstica (FD), em função do tipo de solo e das doses de $\mathrm{Cu}$ aplicadas (Tabela 12), mostram que não houve efeito significativo $(\mathrm{P}<0,01)$, para os dois solos e nem para as doses testadas no experimento.

Tabela 12. Concentrações de $\mathrm{Cu}$ na FD, em função das doses de $\mathrm{Cu}$ aplicadas aos solos (Médias de quatro repetições).

\begin{tabular}{ccc}
\hline $\begin{array}{c}\text { Dose de } \mathrm{Cu} \\
\left(\mathrm{mg} \mathrm{dm}^{-3}\right)\end{array}$ & \multicolumn{2}{c}{ Solo } \\
\cline { 2 - 3 } & AQ & PV \\
\hline 0,0 & $9,7 \mathrm{a} \mathrm{A}$ & $8,5 \mathrm{a} \mathrm{A}$ \\
0,5 & $7,1 \mathrm{a} \mathrm{A}$ & $6,0 \mathrm{a} \mathrm{A}$ \\
1,0 & $6,0 \mathrm{a} \mathrm{A}$ & $6,0 \mathrm{a} \mathrm{A}$ \\
2,0 & $5,7 \mathrm{a} \mathrm{A}$ & $8,6 \mathrm{a} \mathrm{A}$ \\
\hline Médias & $7,1 \mathrm{~A}$ & $7,3 \mathrm{~A}$ \\
\hline DMS & 7,1 & 9,8 \\
CV\% & 33,5 & 33,5 \\
\hline
\end{tabular}

Médias seguidas pela mesma letra maiúscula na horizontal ou minúscula na vertical não diferem significativamente entre si ao nível de $1 \%$, pelo teste de Tukey. 


\subsection{Na planta colhida 30 dias após a emergência}

O resultado da análise do material vegetal seco da aérea da planta de milho colhida aos 30 dias (MSPA1) e as concentrações de $\mathrm{Cu}$ encontradas em função do tipo de solo e das doses de $\mathrm{Cu}$ aplicadas, encontram-se na Tabela 13. Observa-se que a produção de MSPA1 no solo PV fọi estatisticamente superior à produção no solo $\mathrm{AQ}$ e o inverso ocorreu com relação às concentrações de $\mathrm{Cu}$, devido ao efeito de diluição.

\subsection{Na planta colhida ao final do experimento}

As concentrações médias encontradas nas determinações de $\mathrm{Cu}$ no material vegetal seco das plantas de milho, ao final do experimento (MSPA2), são apresentadas na Tabela 14, e estão dentro da faixa de 2 a $20 \mathrm{mg} \mathrm{kg}^{-1}$ de $\mathrm{Cu}$ no material vegetal seco, encontrados por Malavolta et al. (1997); Kabata-Pendias \& Pendias (1984); Mengel \& Kirkby (1987).

Tabela 13. Material vegetal seco da parte aérea das plantas de milho colhidas aos 30 dias (MSPA1) e concentração de $\mathrm{Cu}$, em função das doses aplicadas aos solos (Médias de quatro repetições).

\begin{tabular}{|c|c|c|c|c|}
\hline \multirow{2}{*}{$\begin{array}{c}\text { Dose de Cu } \\
\left(\mathrm{mg} \mathrm{dm}^{-3}\right)\end{array}$} & \multicolumn{2}{|c|}{ MSPA1 } & \multicolumn{2}{|c|}{ Concentração de $\mathrm{Cu}$} \\
\hline & $\mathrm{AQ}$ & PV & $\overline{\mathrm{AQ}}$ & $\overline{\mathrm{PV}}$ \\
\hline & \multicolumn{2}{|c|}{ - } & -- & - \\
\hline 0,0 & 6,3 a A & 2,8 a B & 4,3 a B & 8,3 a $A$ \\
\hline 0,5 & 6,2 a $A$ & 2,9 a B & 7,5 a $B$ & 8,6 a $A$ \\
\hline 1,0 & 6,4 a $A$ & 3,0 a B & 5,4 a B & 9,6 a A \\
\hline 2,0 & 6,9 a $\mathrm{A}$ & 2,7 a B & 5,1 a B & 8,7 a $A$ \\
\hline Médias & $6,4 \mathrm{~A}$ & $2,8 \mathrm{~B}$ & $5,6 \mathrm{~B}$ & $8,8 \mathrm{~A}$ \\
\hline DMS & 2,6 & 3,3 & 6,1 & 2,4 \\
\hline CV\% & 13,5 & 38,6 & 36,6 & 9,0 \\
\hline
\end{tabular}

Médias seguidas pela mesma letra maiúscula na horizontal ou minúscula na vertical não diferem significativamente entre si ao nível de $1 \%$, pelo teste de Tukey. 
A aplicação de $\mathrm{Cu}$ não aumentou a produção de material vegetal seco e nem afetou as concentrações do nutriente no tecido analisado. Observa-se que não houve diferença significativa tanto entre as doses de $\mathrm{Cu}$ quanto entre os solos. Britto et al. (1971); Galrão \& Mesquita Filho (1981); Galrão (1984); Abreu et al (1987) também não encontraram respostas do milho à aplicação de $\mathrm{Cu}$ em diferentes condições e tipos de solo.

Tabela 14. Material vegetal seco da parte aérea das plantas de milho ao final do experimento (MSPA2), concentração e quantidade de $\mathrm{Cu}$ absorvido, em função das doses aplicadas (Médias de quatro repetições).

\begin{tabular}{|c|c|c|c|c|c|c|}
\hline \multirow{2}{*}{$\begin{array}{l}\text { ose de } \mathrm{Cu} \\
\left(\mathrm{mg} \mathrm{dm}^{-3}\right)\end{array}$} & \multicolumn{2}{|c|}{ MSPA2 } & \multicolumn{2}{|c|}{ Concentração de $\mathrm{Cu}$} & \multicolumn{2}{|c|}{ Absorção de $\mathrm{Cu}$} \\
\hline & $\overline{\mathrm{AQ}}$ & $\overline{P V}$ & $\mathrm{AQ}$ & PV & AQ & PV \\
\hline & \multicolumn{2}{|c|}{--g/vaso----..-- } & \multicolumn{2}{|c|}{ mg kg ${ }^{-1}$} & \multicolumn{2}{|c|}{----mg/vaso----- } \\
\hline 0,0 & 29,4 a $\mathrm{A}$ & 23,2 a $A$ & 3,6 a $\mathrm{A}$ & 2,5 a $A$ & $0,10 \mathrm{a} \mathrm{A}$ & $0,06 \mathrm{a} A$ \\
\hline 0,5 & 33,4 a $\mathrm{A}$ & 26,8 a $A$ & 3,7 a $\mathrm{A}$ & 3,1 a $A$ & 0,12 a $A$ & 0,08 a $A$ \\
\hline 1,0 & 28,0 a $\mathrm{A}$ & 32,3 a $A$ & 4,0 a $\mathrm{A}$ & 2,2 a A & 0,11 a $A$ & 0,07 a $A$ \\
\hline 2,0 & 35,5 a $A$ & 27,6 a $A$ & 2,2 a A & $2,4 \mathrm{a} \mathrm{A}$ & 0,08 a A & 0,07 a $A$ \\
\hline Médias & $31,62 \mathrm{~A}$ & $27,49 \mathrm{~A}$ & $3,4 \mathrm{~A}$ & $2,6 \mathrm{~A}$ & $0,10 \mathrm{~A}$ & $0,07 \mathrm{~A}$ \\
\hline CV\% & 22,5 & 13,03 & 49,2 & 15,3 & 43,9 & 22,2 \\
\hline DMS & 0,26 & 10,7 & 4,97 & 1,17 & 1,75 & 0,05 \\
\hline
\end{tabular}

Médias seguidas pela mesma letra minúscula na vertical ou maiúscula na horizontal não diferem significativamente entre si ao nível de $1 \%$, pelo teste de Tukey.

Em experimentos realizados por Lopes (1983) na região dos cerrados com várias culturas, entre elas o milho, não se observou resposta ao $\mathrm{Cu}$. Este autor concluiu que a falta de consistência do nível crítico e, sobretudo o uso de pesticidas à base de $\mathrm{Cu}$ nessa região, fazem com que a necessidade da aplicação desse nutriente não seja tão importante como é a do $\mathrm{Zn}$.

Galrão (1984), estudando em casa-de-vegetação o efeito do $\mathrm{Cu}$ em dez solos de várzea da região dos cerrados, observou efeitos do $\mathrm{Cu}$ sobre a 
produção de material vegetal seco, apenas nos solos com altas concentrações de matéria orgânica.

\subsubsection{Zinco}

\subsubsection{No solo}

As concentrações de zinco, determinadas na análise inicial nos dois tipos de solo (AQ e PV), foram de 0,16 e $0,54 \mathrm{mg} \mathrm{dm}^{-3}$, respectivamente, as quais são consideradas como nível baixo e crítico no solo, respectivamente, por Cox \& Kamprath (1983), porém para Lindsay \& Norvell (1978) e Viets Junior \& Lindsay (1983) são considerados como níveis baixos.

Após a aplicação de $\mathrm{Zn}$ obtiveram-se os resultados que estão na Tabela 15 .

Tabela 15. Concentrações de $\mathrm{Zn}$ nos solos AQ e PV solo em função das doses aplicadas.

\begin{tabular}{|c|c|c|}
\hline \multirow{2}{*}{$\begin{array}{l}\text { Dose de } \mathrm{Zn} \\
\left(\mathrm{mg} \mathrm{dm}^{-3}\right)\end{array}$} & \multicolumn{2}{|c|}{ Solo } \\
\hline & $\mathrm{AQ}$ & PV \\
\hline & - & . \\
\hline 0,0 & $0,28 \mathrm{~b}$ & $0,68 \mathrm{c}$ \\
\hline 0,7 & $0,64 \mathrm{a}$ & $1,45 \mathrm{c}$ \\
\hline 1,4 & $0,81 \mathrm{a}$ & $4,24 \mathrm{~b}$ \\
\hline 2,8 & $0,97 \mathrm{a}$ & $7,53 \mathrm{a}$ \\
\hline Médias & $0,67 \mathrm{~B}$ & $3,47 \mathrm{~A}$ \\
\hline CV\% & 17,50 & 12,50 \\
\hline DMS & 0,60 & 1,29 \\
\hline
\end{tabular}

Médias seguidas pela mesma letra minúscula na vertical ou maiúscula na horizontal não diferem significativamente entre si ao nível de $1 \%$, pelo teste de Tukey.

Observa-se que em ambos os solos ocorreram aumentos significativos nas concentrações de $\mathrm{Zn}$, em função das doses aplicadas. No solo 
$\mathrm{AQ}$ a concentração do nutriente na dose zero $\mathrm{mg} \mathrm{dm}^{-3}$ é considerada como baixa e, nas doses 0,$7 ; 1,4$ e 2,8 como média, enquanto que no solo PV as concentrações estão entre os limites considerados como média (dose zero), adequada (doses 0,7 e 1,4) e alta (dose 2,8) por Malavolta (1987) e Abreu (1995).

Verifica-se que as concentrações de Zn no solo PV são maiores que no solo $\mathrm{AQ}$ em todos os tratamentos e isso deve estar associado à textura do solo. Provavelmente a fração grosseira do solo PV apresenta ilmenita e magnetita, minerais ricos em $\mathrm{Zn}$ (Valadares \& Catani, 1975). Esses autores afirmam que solos derivados de rochas básicas são os mais ricos em $\mathrm{Zn}$ e, os derivados de sedimentos arenosos são os mais pobres.

\subsubsection{Na parte aérea da planta}

\subsection{Na folha diagnóstica}

As concentrações de $\mathrm{Zn}$ na folha diagnóstica (FD) em função do tipo de solo (AQ e PV), aos quais aplicou-se doses de $\mathrm{Zn}$ são apresentados na Tabela 16. As concentrações de $\mathrm{Zn}$ aumentaram em função das doses aplicadas em ambos os solos. No solo AQ a maior concentração de $\mathrm{Zn}$ ocorreu quando se aplicou $\mathrm{Zn}$ no solo na dose mais alta $\left(2,8 \mathrm{mg} \mathrm{dm}^{-3}\right)$, seguido da dose 1,4 que foi semelhante estatisticamente às doses 0,7 e 0 . No solo PV, a maior concentração de $\mathrm{Zn}$ também foi encontrada na dose 2,8, seguidas das doses 1,4 e 0,7 em que as concentrações de $\mathrm{Zn}$ no tecido foram semelhantes estatisticamente. Observa-se ainda, que as concentrações de $\mathrm{Zn}$ no solo $\mathrm{PV}$ foram significativamente $(\mathrm{P}<0,01)$ superiores às encontradas no solo $\mathrm{AQ}$, seguramente devido às concentrações iniciais desse nutriente naquele solo serem superiores, e à textura do solo, que favoreceu a sua maior absorção pela parte aérea das plantas de milho. 
Tabela 16. Concentração de $\mathrm{Zn}$ na folha diagnóstica (FD), em função das doses de $\mathrm{Zn}$ aplicadas e do tipo de solo (Médias de quatro repetições).

\begin{tabular}{ccc}
\hline $\begin{array}{c}\text { Dose de } \mathrm{Zn} \\
\left(\mathrm{mg} \mathrm{dm}^{-3}\right)\end{array}$ & \multicolumn{2}{c}{ Solo } \\
\cline { 2 - 3 } 0,0 & $\mathrm{AQ}$ & $\mathrm{PV}$ \\
\hline 0,7 & $5,8 \mathrm{~b} \mathrm{~B}$ & $12,9 \mathrm{c} \mathrm{A}$ \\
1,4 & $6,8 \mathrm{~b} \mathrm{~B}$ & $24,1 \mathrm{~b} \mathrm{~A}$ \\
2,8 & $10,3 \mathrm{~b} \mathrm{~B}$ & $27,6 \mathrm{~b} \mathrm{~A}$ \\
\hline Médias & $17,0 \mathrm{a} \mathrm{B}$ & $36,9 \mathrm{a} \mathrm{A}$ \\
\hline CV\% & $10,0 \mathrm{~B}$ & $25,4 \mathrm{~A}$ \\
\hline DMS & 4,9 & 5,6 \\
\hline
\end{tabular}

Médias seguidas pela mesma letra minúscula na vertical ou maiúscula na horizontal não diferem significativamente entre si ao nível de $1 \%$, pelo teste de Tukey.

\subsection{Na planta colhida 30 dias após a emergência}

A análise do material vegetal seco das plantas de milho colhidas aos 30 dias após a emergência (MSPA1) e a concentração de Zn na parte aérea das plantas de milho em função das doses aplicadas aos solos, é apresentada na Tabela 17.

A produção de material vegetal seco não foi afetada pelo aumento das doses de $\mathrm{Zn}$ em ambos os solos, sendo que no solo AQ essa produção foi maior. Já as concentrações de $\mathrm{Zn}$ no tecido aumentaram significativamente em função das doses aplicadas aos solos. As concentrações de $\mathrm{Zn}$ no solo PV foram mais elevadas do que no solo $\mathrm{AQ}$, porém isso deveu-se somente ao efeito de diluição. 
Tabela 17. Material vegetal seco da parte aérea 30 dias após a emergência (MSPAl) e concentração de $\mathrm{Zn}$, em função das doses aplicadas aos solos (Médias de quatro repetições).

\begin{tabular}{|c|c|c|c|c|}
\hline \multirow{2}{*}{$\begin{array}{c}\text { Dose de } \mathrm{Zn} \\
\left(\mathrm{mg} \mathrm{dm}^{-3}\right)\end{array}$} & \multicolumn{2}{|c|}{ MSPA1 } & \multicolumn{2}{|c|}{$\mathrm{Zn}$} \\
\hline & $\mathrm{AQ}$ & PV & AQ & PV \\
\hline & & & & \\
\hline 0,0 & 6,1 a $A$ & 2,6 a B & 14,4 c B & 28,8 с A \\
\hline 0,7 & 6,3 a $A$ & 2,7 a B & 17,9 с B & 70,9 b c A \\
\hline 1,4 & 6,2 a $A$ & 3,2 a $\mathrm{B}$ & 28,4 b B & $95,2 \mathrm{ab} A$ \\
\hline 2,8 & 5,9 a $\mathrm{A}$ & 2,9 a B & 44,8 a B & 144,8 a $A$ \\
\hline Médias & $6,1 \mathrm{~A}$ & $2,8 \mathrm{~B}$ & $26,4 \mathrm{~B}$ & $85,0 \mathrm{~B}$ \\
\hline CV\% & 13,3 & 40,5 & 15,0 & 25,0 \\
\hline DMS & 2,4 & 3,4 & 11,8 & 63,3 \\
\hline
\end{tabular}

Médias seguidas pela mesma letra minúscula na vertical ou maiúscula na horizontal não diferem significativamente entre si ao nível de $1 \%$, pelo teste de Tukey.

\subsection{Na planta colhida ao final do experimento}

A análise estatística revelou que a produção de material vegetal seco da parte aérea das plantas de milho, bem como as concentrações de $\mathrm{Zn}$ e a quantidade de $\mathrm{Zn}$ absorvida diferiram significativamente $(\mathrm{P}<0,01)$ da testemunha (dose $0 \mathrm{mg} \mathrm{dm}^{-3}$ ), aumentando à medida que as doses de $\mathrm{Zn}$ aplicadas aos solos aumentaram (Tabela 18).

A maior produção de material vegetal seco foi obtida com a aplicação de $2,8 \mathrm{mg} \mathrm{dm}^{-3}$ nos solos AQ e PV. O aumento provocado por essa dose foi pelo menos duas vezes maior do que na testemunha (dose $0 \mathrm{mg} \mathrm{dm}^{-3}$ ). Em média, a produção de material vegetal seco foi significativamente mais elevada no solo PV. As concentrações médias de Zn estão dentro da faixa de 15 a $50 \mathrm{mg}$ $\mathrm{kg}^{-1}$ (dose 0,7 a 2,8 no solo AQ e dose 0 a 1,4 no solo PV) encontradas por Malavolta (1997). A maior concentração de Zn no tecido foi obtida quando aplicou-se $2,8 \mathrm{mg} \mathrm{dm}^{-3}$ (dose maior) do nutriente em ambos os solos, mas, foi 
Tabela 18. Material vegetal seco produzido ao final do experimento (MSPA2), concentração e quantidade de $\mathrm{Zn}$ absorvida, em função das doses de $\mathrm{Zn}$ aplicadas os solos AQ e PV (Médias de quatro repetições).

\begin{tabular}{|c|c|c|c|c|c|c|}
\hline \multirow{2}{*}{$\begin{array}{l}\text { ose de } \mathrm{Zn} \\
\left(\mathrm{mg} \mathrm{dm}^{-3}\right)\end{array}$} & \multicolumn{2}{|c|}{ MSPA2 } & \multicolumn{2}{|c|}{ Concentração de $\mathrm{Zn}$} & \multicolumn{2}{|c|}{ Absorção de Zn } \\
\hline & $\overline{\mathrm{AQ}}$ & PV & $\mathrm{AQ}$ & PV & $\overline{\mathrm{AQ}}$ & PV \\
\hline & \multicolumn{2}{|c|}{ 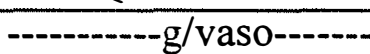 } & \multirow{2}{*}{\multicolumn{2}{|c|}{ mg kg ${ }^{-1}-$}} & \multirow{2}{*}{\multicolumn{2}{|c|}{---mg/vaso--.-- }} \\
\hline 0,0 & $19,0 \mathrm{cB}$ & $28,6 \mathrm{cA}$ & & & & \\
\hline 0,7 & $36,4 \mathrm{bA}$ & $37,9 \mathrm{bA}$ & $21,5 \mathrm{bB}$ & $33,5 \mathrm{cA}$ & $0,8 \mathrm{bB}$ & $1,3 \mathrm{cA}$ \\
\hline 1,4 & $40,1 \mathrm{bA}$ & $42,8 \mathrm{bA}$ & $28,1 \mathrm{baB}$ & $54,2 \mathrm{bA}$ & $1,1 \mathrm{bB}$ & $2,3 \mathrm{bA}$ \\
\hline 2,8 & $48,3 \mathrm{aA}$ & $55,4 \mathrm{aA}$ & $34,8 \mathrm{aB}$ & $100,0 \mathrm{aA}$ & $1,7 \mathrm{aB}$ & $5,5 \mathrm{aA}$ \\
\hline Médias & $35,9 \mathrm{~B}$ & $41,2 \mathrm{~A}$ & $23,6 \mathrm{~B}$ & $51,0 \mathrm{~A}$ & $0,9 \mathrm{~B}$ & $2,4 \mathrm{~A}$ \\
\hline CV\% & 6,7 & 5,8 & 7,3 & 8,7 & 0,4 & 0,6 \\
\hline DMS & 6,3 & 4,8 & 10,4 & 5,8 & 14,4 & 8,4 \\
\hline
\end{tabular}

Médias seguidas pela mesma letra minúscula na vertical ou maiúscula na horizontal não diferem significativamente entre si ao nível de $1 \%$, pelo teste de Tukey.

estatisticamente semelhante à dose $1,4 \mathrm{mg} \mathrm{dm}^{-3}$ no solo AQ e, praticamente, o mesmo comportamento foi observado ao analisar-se a quantidade de $\mathrm{Zn}$ absorvida pela parte aérea das plantas de milho.

Os aumentos de produção de material vegetal seco e da quantidade de $\mathrm{Zn}$ absorvida pela parte aérea das plantas de milho em função do aumento das doses aplicadas aos solos, ajustaram-se significativamente a modelos quadráticos em ambos os solos (Figuras 5 e 6). A relação entre a produção de material vegetal seco e as doses de $\mathrm{Zn}$, resultou em curvas semelhantes, com uma ligeira vantagem para o solo PV e coeficientes de determinação iguais em ambos os solos $\left(\mathrm{R}^{2}=0,92\right)$. Por outro lado, a relação entre a quantidade de $\mathrm{Zn}$ absorvida e as doses foi melhor no solo PV $\left(\mathrm{R}^{2}=0,98\right)$ do que no solo $\mathrm{AQ}\left(\mathrm{R}^{2}=0,95\right)$ e as curvas demonstram que no solo PV, as plantas de milho acumularam maior quantidade de $\mathrm{Zn}$. 


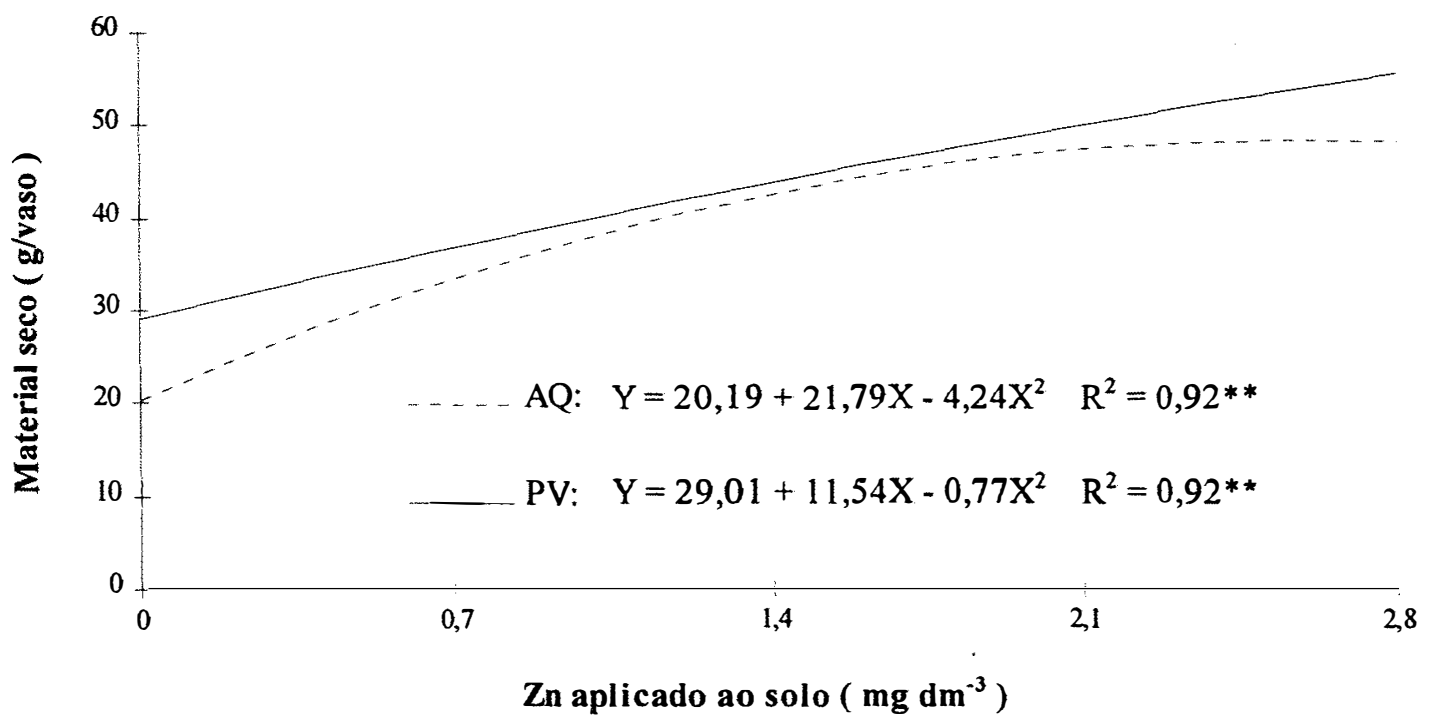

Figura 5. Relação entre o $\mathrm{Zn}$ aplicado aos solos $A Q$ e $P V$ e a produção de material vegetal seco na parte aérea das plantas de milho.

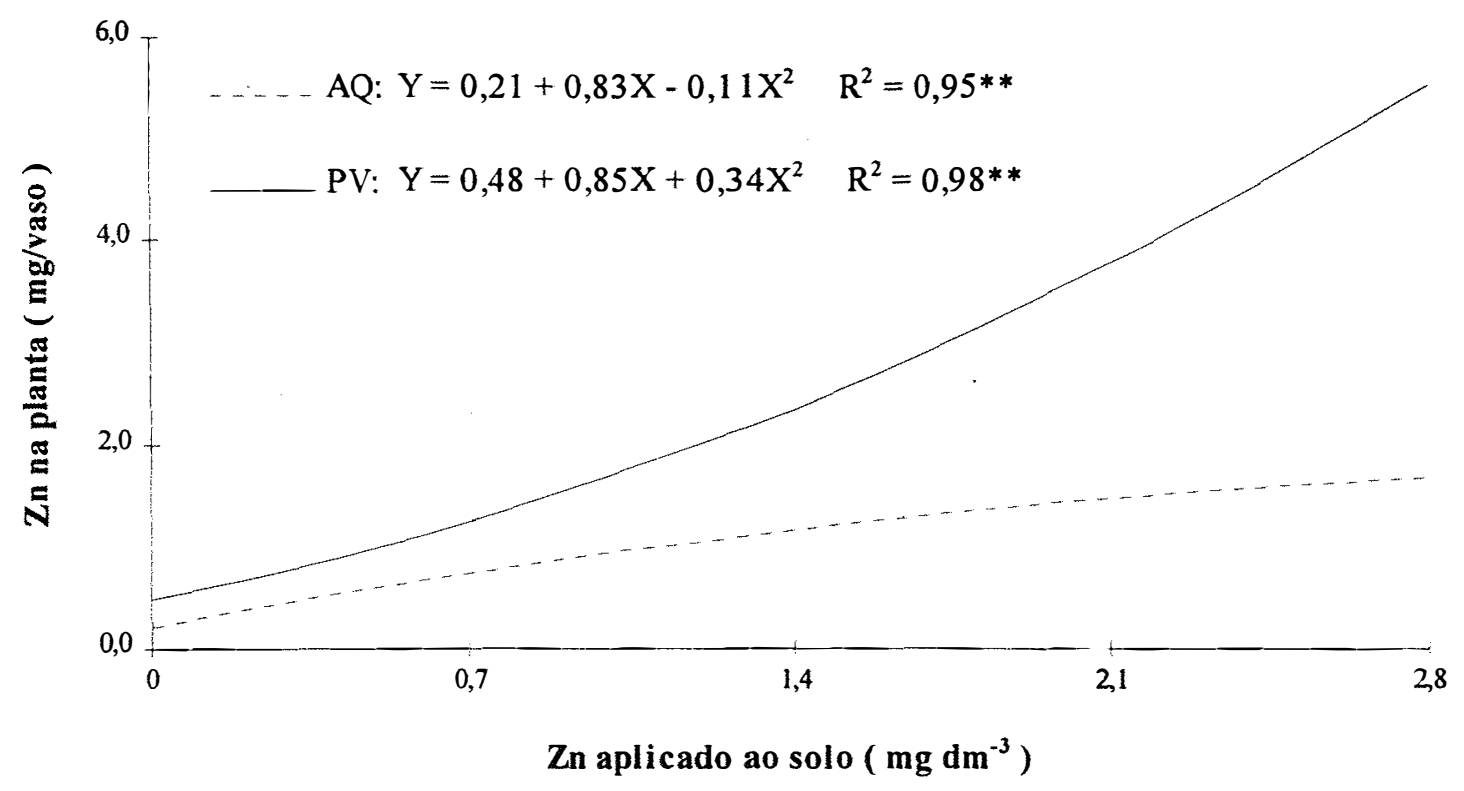

Figura 6. Relação entre o $\mathrm{Zn}$ aplicado aos solos $\mathrm{AQ}$ e $\mathrm{PV}$ e a quantidade de $\mathrm{Zn}$ na parte aérea das plantas de milho. 
Derivando-se as equações da Figura 6, encontrou-se as doses que propiciaram a produção máxima de material vegetal seco da parte aérea das plantas de milho (100\%), que foram 2,57 e 7,49 $\mathrm{mg} \mathrm{dm}^{-3}$ para os solos AQ e PV, respectivamente. Após o cálculo de $90 \%$ da produção máxima de material vegetal seco, encontrou-se as doses que correspondem à zona adequada ou nível crítico e, que foram 1,5 e 4,4 $\mathrm{mg} \mathrm{dm}^{-3}$ para os solos AQ e PV, respectivamente.

Diversos autores também encontraram resposta do milho à aplicação de $\mathrm{Zn}$ no solo sob diferentes condições e tipos de solo (Ritchey et al., 1986, Couto et al., 1992, Bataglia \& Raij, 1994 e Galrão, 1996; entre outros).

\subsubsection{Avaliação de extratores para zinco e cobre}

As concentrações de zinco e cobre nos solos AQ e PV depois da colheita, obtidas com os extratores DTPA-TEA, $\mathrm{HCl}$ 0,1M, Mehlichl e Mehlich3, foram relacionadas com as quantidades desses nutrientes aplicadas aos solos, e com a quantidade acumulada dos mesmos na parte aérea das plantas de milho, apenas ao final do experimento.

\subsubsection{Cobre}

A Tabela 19 apresenta as concentrações de $\mathrm{Cu}$ recuperadas pelos extratores, para cada solo estudado, em função das doses de $\mathrm{Cu}$ aplicadas. Verifica-se que a maior extração de $\mathrm{Cu}$ foi obtida quando se utilizou o Mehlich1, seguido do Mehlich3, e finalmente $\mathrm{HCl}$ e DTPA-TEA. 
Tabela 19. Concentrações de $\mathrm{Cu}$ disponíveis no solo avaliadas com os extratores DTPA-TEA, $\mathrm{HCl}$, Mehlich1 e Mehlich3, após a colheita da parte aérea das plantas de milho, em resposta às doses de $\mathrm{Cu}$ aplicadas em dois solos (Médias de quatro repetições).

\begin{tabular}{ccccccc}
\hline \multirow{2}{*}{ Solo } & Dose de $\mathrm{Cu}$ & \multicolumn{5}{c}{ Concentração de Cu } \\
\cline { 2 - 6 } AQ & DTPA-TEA & HCl & Mehlich1 & Mehlich3 & Cu absorvido \\
\hline & 0,0 & $0,23 \mathrm{~B}$ & $0,25 \mathrm{~B}$ & $12,30 \mathrm{~A}$ & $7,57 \mathrm{~A}$ & $0,10 \mathrm{a}$ \\
& 0,5 & $0,38 \mathrm{C}$ & $0,30 \mathrm{C}$ & $12,18 \mathrm{~A}$ & $9,09 \mathrm{~B}$ & $0,12 \mathrm{a}$ \\
& 1,0 & $0,43 \mathrm{C}$ & $0,43 \mathrm{C}$ & $11,98 \mathrm{~A}$ & $8,60 \mathrm{~B}$ & $0,11 \mathrm{a}$ \\
& 2,0 & $0,41 \mathrm{C}$ & $0,35 \mathrm{C}$ & $12,40 \mathrm{~A}$ & $8,79 \mathrm{~B}$ & $0,08 \mathrm{a}$ \\
\hline PV & 0,0 & $0,45 \mathrm{C}$ & $0,63 \mathrm{C}$ & $8,90 \mathrm{~A}$ & $4,70 \mathrm{~B}$ & $0,06 \mathrm{a}$ \\
& 0,5 & $0,57 \mathrm{C}$ & $0,83 \mathrm{C}$ & $9,80 \mathrm{~A}$ & $4,91 \mathrm{~B}$ & $0,08 \mathrm{a}$ \\
& 1,0 & $0,86 \mathrm{C}$ & $0,85 \mathrm{C}$ & $8,93 \mathrm{~A}$ & $4,39 \mathrm{~B}$ & $0,07 \mathrm{a}$ \\
& 2,0 & $1,05 \mathrm{C}$ & $0,80 \mathrm{C}$ & $8,68 \mathrm{~A}$ & $4,89 \mathrm{~B}$ & $0,07 \mathrm{a}$ \\
\hline
\end{tabular}

Médias seguidas pela mesma letra maiúscula na horizontal ou minúscula na vertical não diferem significativamente entre si ao nível de $1 \%$, pelo teste de Tukey.

$\mathrm{Na}$ Figura 7 são apresentadas as correlações entre o $\mathrm{Cu}$ aplicado aos solos e o $\mathrm{Cu}$ recuperado pelos extratores DTPA-TEA, $\mathrm{HCl}$, Mehlich1 e Mehlich3. Observa-se que essas correlações foram significativas para todos os extratores, exceto para o extrator $\mathrm{HCl}$ e a melhor correlação deu-se quando o $\mathrm{Cu}$ foi extraído pelo método DTPA-TEA, $\mathrm{R}^{2}=0,93$ e $\mathrm{R}^{2}=0,86$, para os solos AQ e PV, respectivamente. Nenhum dos extratores correlacionou-se significativamente com a quantidade de $\mathrm{Cu}$ absorvida pela parte aérea das plantas de milho (Figuras $8 \mathrm{e}$ 9).

\subsubsection{Zinco}

Com relação aos extratores para $\mathrm{Zn}$, para cada solo estudado em função das doses de $\mathrm{Zn}$ aplicadas (Tabela 20) verifica-se que a maior extração 
de $\mathrm{Zn}$ foi obtida quando se utilizou o Mehlich1, vindo a seguir o extrator Mehlich3, depois o $\mathrm{HCl}$ e, finalmente o DTPA-TEA. O maior poder de extração

Tabela 20. Concentrações de $\mathrm{Zn}$ disponível no solo avaliadas com os extratores DTPA-TEA, $\mathrm{HCl}$, Mehlich1 e Mehlich3 após a colheita da parte aérea das plantas de milho, em resposta às doses de $\mathrm{Zn}$ aplicadas em dois solos (Médias de quatro repetições).

\begin{tabular}{lcrrrrr}
\hline & & \multicolumn{5}{c}{ Concentração de Zn } \\
\cline { 2 - 5 } Solo & Dose de Zn & DTPA-TEA & \multicolumn{1}{c}{$\mathrm{HCl}$} & Mehlichl & Mehlich3 & Zn absorvido \\
\hline \multirow{3}{*}{ AQ } & 0,0 & $0,50 \mathrm{~B}$ & $0,50 \mathrm{~B}$ & $1,50 \mathrm{~A}$ & $0,78 \mathrm{~B}$ & mg/vaso \\
& 0,7 & $0,55 \mathrm{~B}$ & $0,83 \mathrm{~B}$ & $2,13 \mathrm{~A}$ & $1,30 \mathrm{~B}$ & $0,79 \mathrm{~b}$ \\
& 1,4 & $0,25 \mathrm{D}$ & $1,43 \mathrm{C}$ & $3,45 \mathrm{~A}$ & $2,23 \mathrm{~B}$ & $1,13 \mathrm{~b}$ \\
& 2,8 & $0,50 \mathrm{D}$ & $2,53 \mathrm{C}$ & $5,78 \mathrm{~A}$ & $4,15 \mathrm{~A}$ & $1,69 \mathrm{a}$ \\
\hline PV & 0,0 & $1,25 \mathrm{~B}$ & $3,33 \mathrm{~A}$ & $2,68 \mathrm{~B}$ & $3,30 \mathrm{~A}$ & $0,47 \mathrm{~d}$ \\
& 0,7 & $2,25 \mathrm{~B}$ & $5,03 \mathrm{~B}$ & $11,83 \mathrm{~A}$ & $4,90 \mathrm{~B}$ & $1,27 \mathrm{c}$ \\
& 1,4 & $3,65 \mathrm{~B}$ & $6,15 \mathrm{~B}$ & $14,25 \mathrm{~A}$ & $4,45 \mathrm{~B}$ & $2,32 \mathrm{~b}$ \\
& 2,8 & $12,35 \mathrm{~B}$ & $16,83 \mathrm{~B}$ & $41,80 \mathrm{~A}$ & $13,43 \mathrm{~B}$ & $5,55 \mathrm{a}$ \\
\hline
\end{tabular}

Médias seguidas pela mesma letra maiúscula na horizontal ou minúscula na vertical não diferem significativamente entre si ao nível de $1 \%$, pelo teste de Tukey.

de $\mathrm{Zn}$ apresentado pelo Mehlich1, confirma os resultados obtidos por Wear \& Evans (1968); Lantmann \& Meurer (1982); Ribeiro \& Tucunango Sarabia (1984). As diferenças entre os extratores, principalmente quando se comparam extratores ácidos com o DTPA-TEA (extrator alcalino), devem-se provavelmente à acidez elevada dos primeiros, que extraem parte do Zn que o DTPA-TEA não consegue (Lantmann \& Meurer, 1982; Ritchey et al., 1986; Bataglia \& Raij, 1990; Buzetti, 1992). 


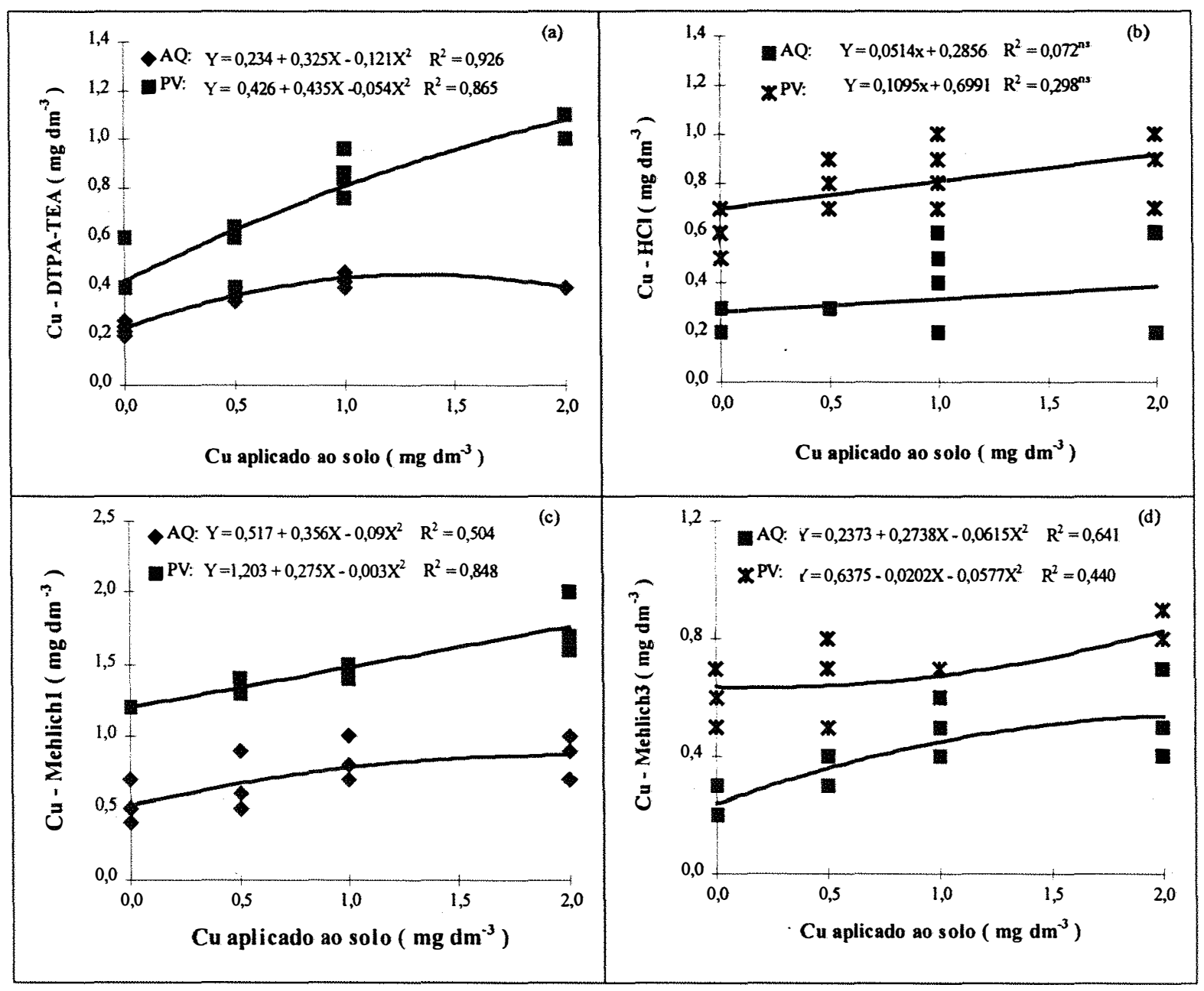

Figura 7. Relação entre o cobre aplicado aos solos AQ e PV e o cobre recuperado pelo extrator DTPA-TEA (a), HCl 0,1M (b), Mehlich1 (c) e Mehlich3 (d). 


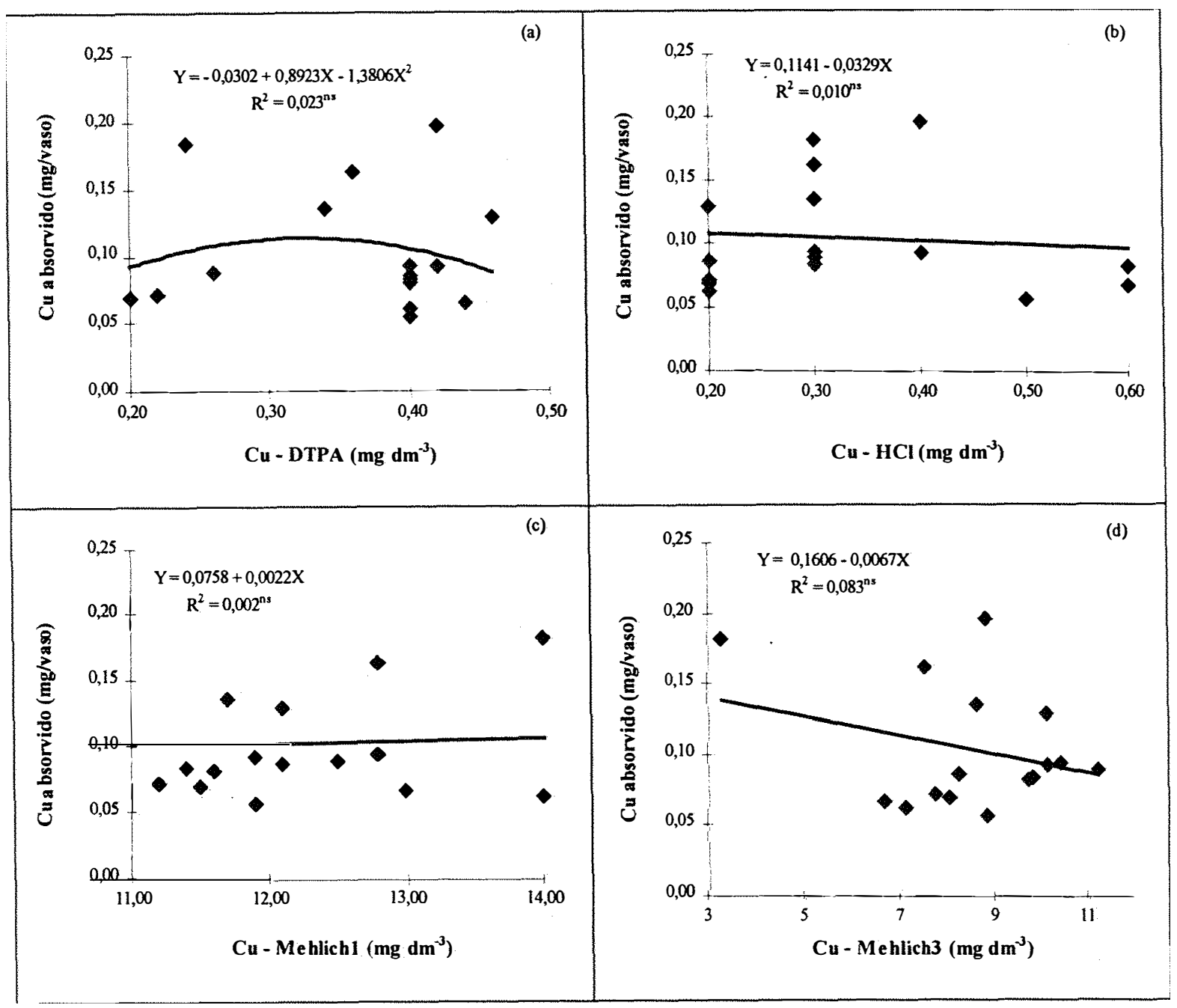

Figura 8. Relação entre o $\mathrm{Cu}$ absorvido pela parte aérea das plantas de milho e o $\mathrm{Cu}$ extraído do solo AQ pelo DTPA-TEA (a), $\mathrm{HCl}$ 0,1M (b), Mehlich1 (c) e Mehlich3 (d). 


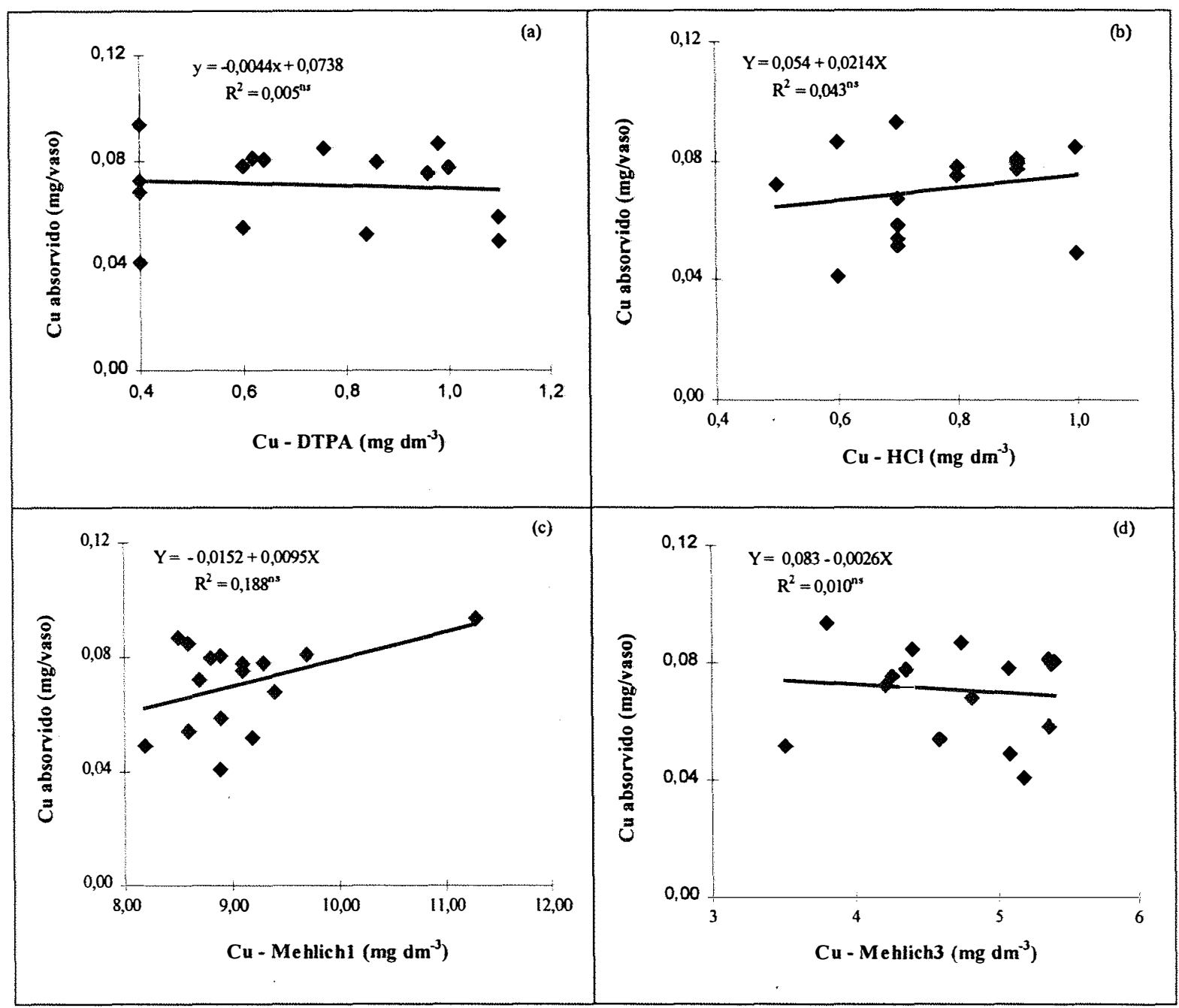

Figura 9. Relação entre o $\mathrm{Cu}$ absorvido pela aérea das plantas de milho e o $\mathrm{Cu}$

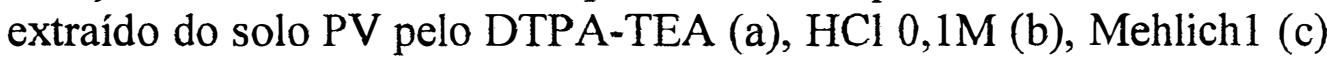
e Mehlich3 (d) 
As correlações entre o $\mathrm{Zn}$ aplicado aos solos e o $\mathrm{Zn}$ recuperado pelos extratores DTPA-TEA, HCl, Mehlich1 e Mehlich3 (Figura 10) mostram que as concentrações de $\mathrm{Zn}$ disponível aumentaram de forma quadrática em função das doses de $\mathrm{Zn}$ aplicadas aos solos, porém o extrator $\mathrm{HCl}$ foi o que melhor relacionou-se com esse parâmetro.

As relações entre o $\mathrm{Zn}$ absorvido pelas plantas de milho e o recuperado pelos extratores, $\mathrm{HCl}$, Mehlich1 e Mehlich3 (Figuras 11 e 12) mostram que os extratores Mehlich1 e Mehlich3 $\left(R^{2}=0,91\right.$ e $R^{2}=0,90$; respectivamente) foram melhores para recuperar o $\mathrm{Zn}$ disponível do solo $\mathrm{AQ}$. Esses resultados são contrários àqueles obtidos por Lantman \& Meurer (1982) e Ribeiro \& Tucunango Sarabia (1984), os quais encontraram que o DTPA-TEA funcionava melhor como extrator para $\mathrm{Zn}$.

No solo PV os extratores $\mathrm{HCl}$ e DTPA-TEA funcionaram melhor para recuperar o $\mathrm{Zn}$ disponível. Esses resultados concordam com os encontrados por Lantman \& Meurer (1982) \& Ribeiro e Tucunango Sarabia (1984). Demonstrando que os extratores de $\mathrm{Zn}$ comportam-se de maneira diferente, dependendo das condições ambientais e do tipo de solo. 


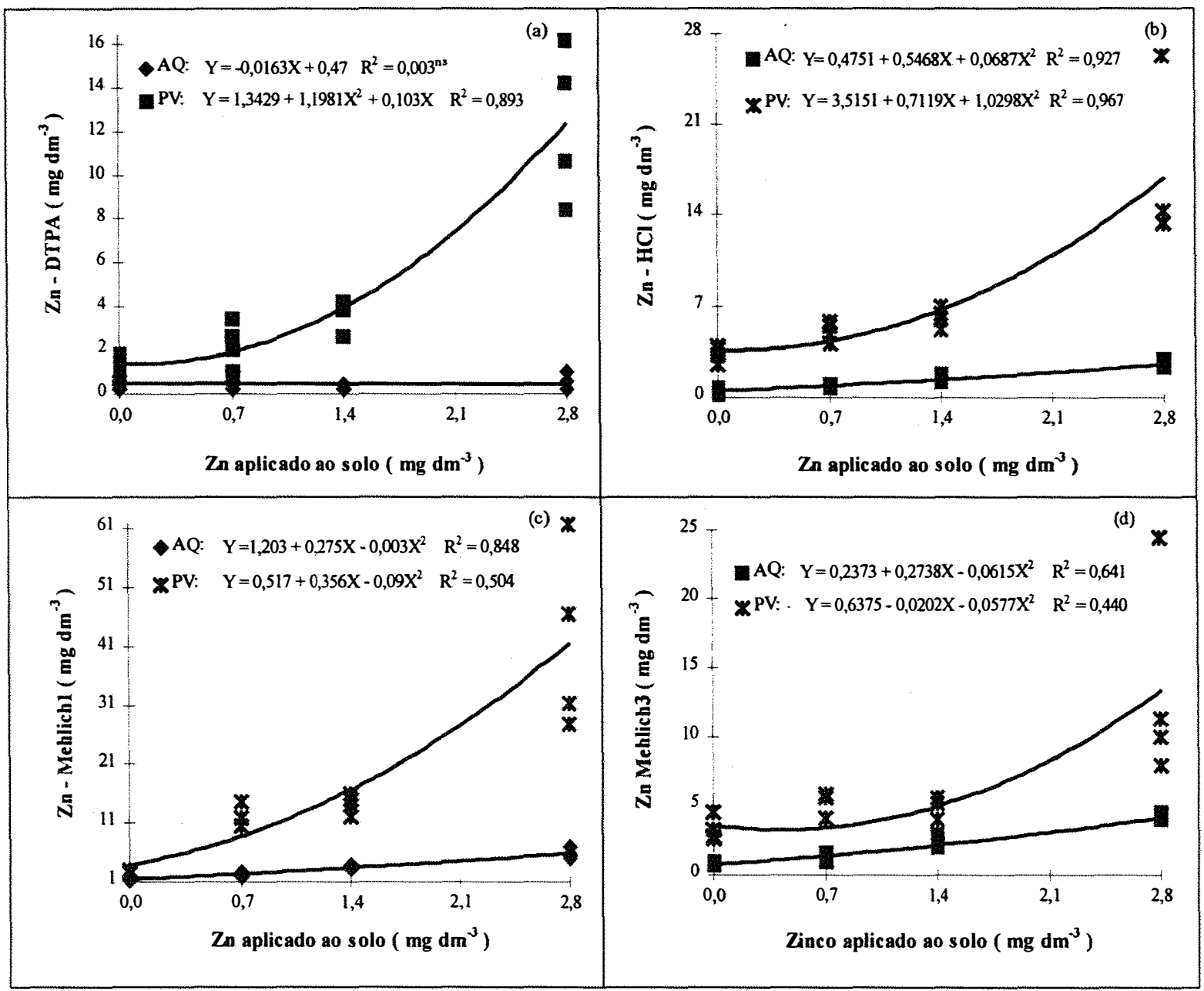

Figura 10. Relação entre o $\mathrm{Zn}$ aplicado aos solos $\mathrm{AQ}$ e $\mathrm{PV}$ e o $\mathrm{Zn}$ recuperado pelo extrator DTPA-TEA (a), $\mathrm{HCl} 0,1 \mathrm{M}$ (b), Mehlich1 (c) e Mehlich3 (d). 


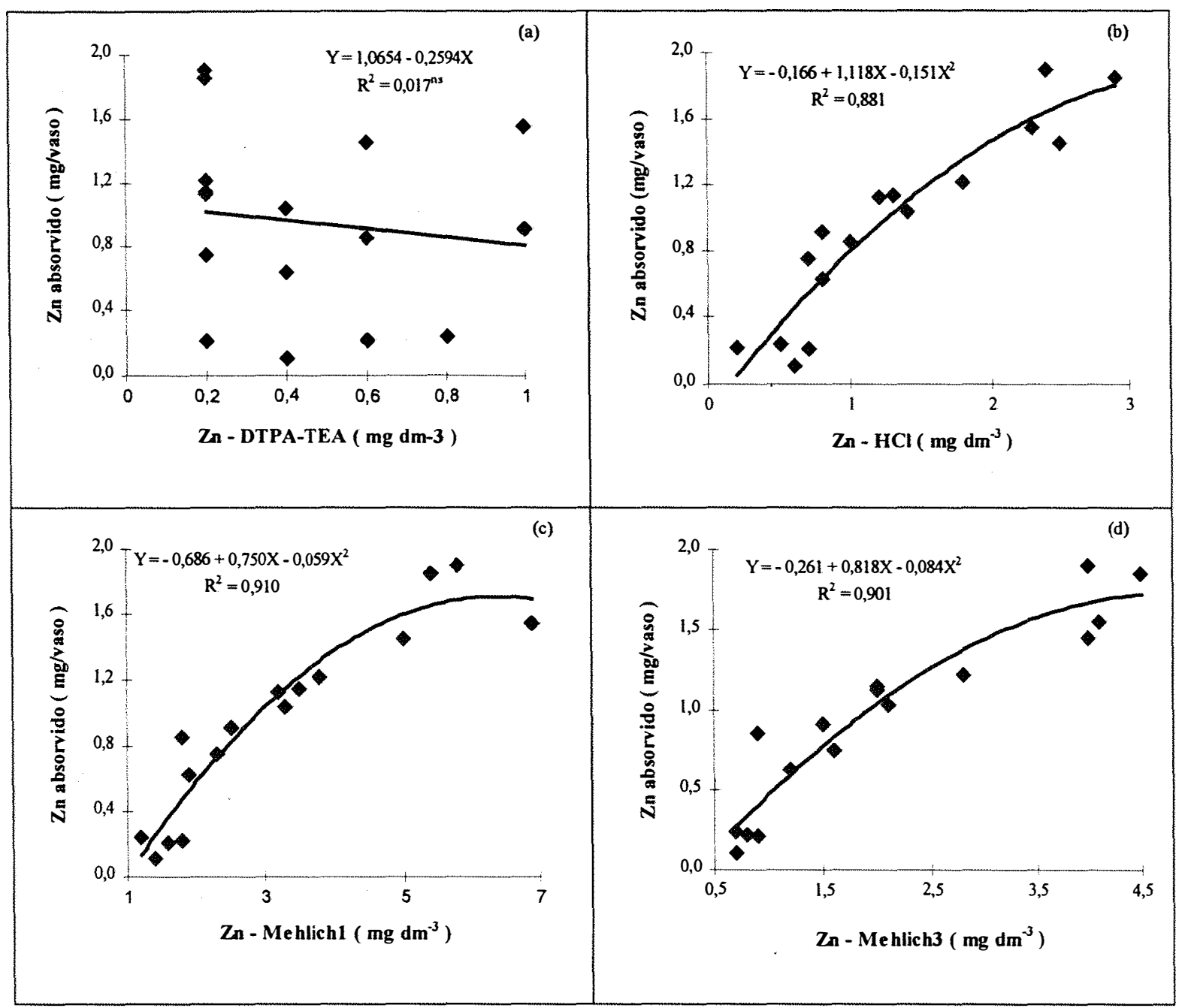

Figura 11. Relação entre o $\mathrm{Zn}$ absorvido pela parte aérea das plantas de milho e o Zn extraído do solo AQ pelo DTPA-TEA (a), $\mathrm{HCl} 0,1 \mathrm{M}$ (b), Mehlich1 (c) e Mehlich3 (d). 


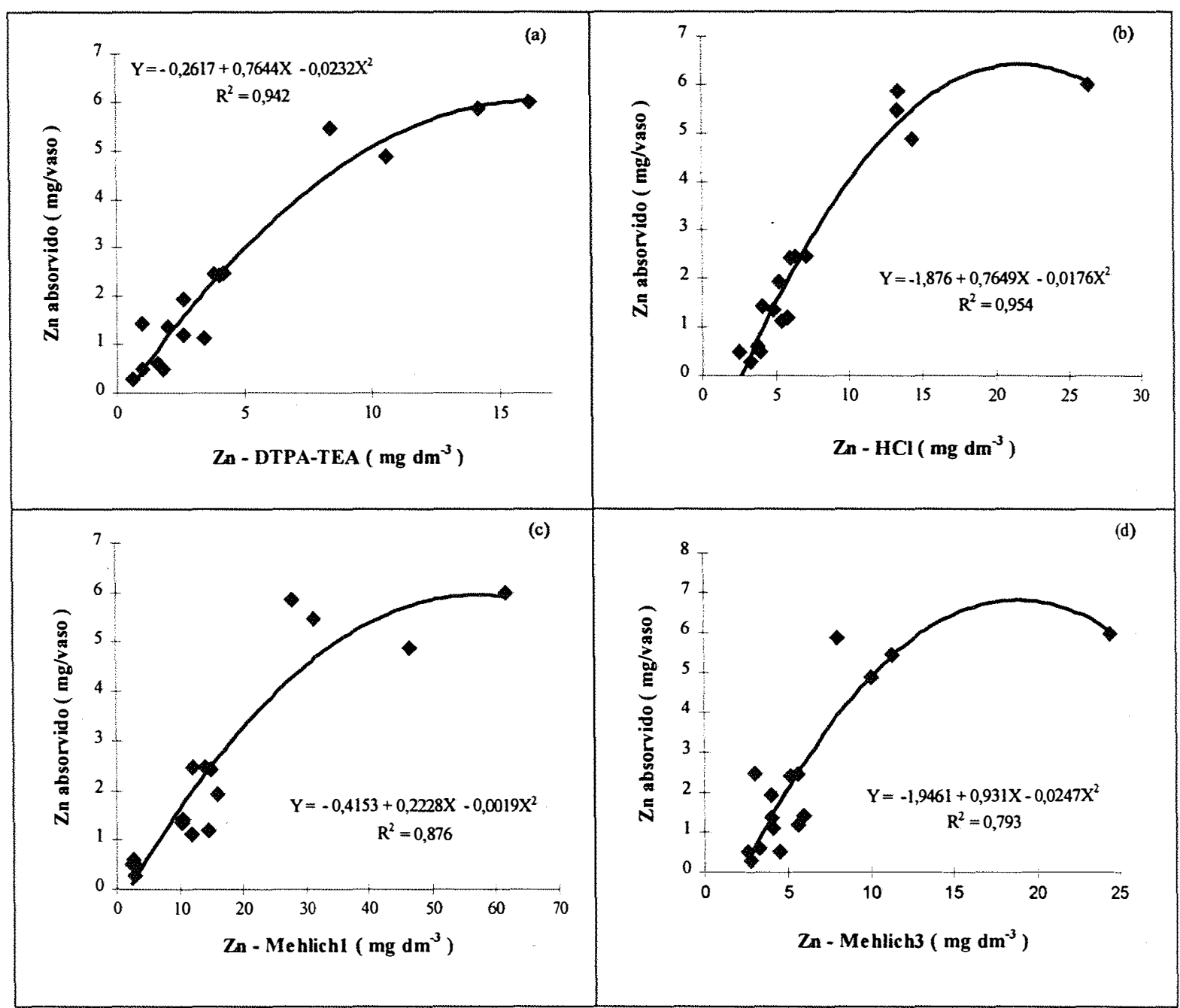

Figura 12. Relação entre o $\mathrm{Zn}$ absorvido pela parte aérea das plantas de milho e o Zn extraído do solo PV pelo DTPA-TEA (a), $\mathrm{HCl} 0,1 \mathrm{M}$ (b), Mehlichl (c) e Mehlich3 (d). 


\section{CONCLUSÕES}

Nas condições em que foram realizados os experimentos, pode-se tirar as seguintes conclusões:

- A adição de boro, cobre e zinco proporcionou aumentos nos teores desses nutrientes no solo e na planta, entretanto, apenas o zinco influenciou significativamente a produção de material seco.

- As doses $0,1 \mathrm{mg} \mathrm{L}^{-1}$ em solução e $2,8 \mathrm{mg} \mathrm{dm}^{-3}$ de $\mathrm{Zn}$ no solo, foram suficientes para obter-se a maior produção de material seco.

- O extrator Mehlich1 recuperou os maiores teores de cobre e zinco em ambos os solos.

- O extrator que melhor correlacionou-se com o cobre aplicado aos solos foi o DTPA-TEA, mas nenhum dos extratores correlacionou-se com o cobre absorvido pelo milho.

- O extrator que melhor correlacionou-se com o zinco aplicado aos solos foi o $\mathrm{HCl}$ 0,1M. O extrator DTPA-TEA teve uma boa correlação com o zinco absorvido pelo milho apenas no solo PV. 


\section{REFERÊNCIAS BIBLIOGRÁFICAS}

ABREU, C. A. Análise do solo para micronutrientes: tema de reuniões de laboratórios. Boletim informativo da Sociedade Brasileira de Ciência do Solo, v.20, p.128-130, 1995.

ABREU, C. A.; LOPES, A.S.; ANDRADE D.S. de. Identificação de deficiências de micronutrientes em cinco solos de várzeas da região de cerrados de Minas Gerais. Pesquisa Agropecuária Brasileira. v.22, p.833-841, ago. 1987.

ADRIANO, D.C. Trace elements in the terrestrial environment. New York: Springer-Verlag, 1986.533p.

ALVAREZ V., V.H.; NOVAIS, R.F.; BRAGA, J.M. et al. Avaliação da fertilidade do solo - metodologia. In: SIMPÓSIO DA PESQUISA NA UFV, Viçosa, 1988. Resumos. Viçosa: UFV. p.68-69.

ANDRADE, A G.; HAAG, H. P.; OLIVEIRA, G. D. Acumulação diferencial de nutrientes por cinco cultivares de milho (Zea mays L.). I. Acumulação de macronutrientes. Anais da Escola Superior de Agricultura "Luiz de Queiroz", v.32, p.115-149, 1975.

AUBERT, H.; PINTA, M. Trace elements in soils. Amsterdam: Elsevier, 1977. $395 \mathrm{p}$.

BAKER, D.E. Copper. In: ALLOWAY, B.J. (Coord.) Heavy metals in soils. New York: John Wiley, 1990. p.151-76.

BARBOSA FILHO, M. P. Nutrição e adubação do arroz (sequeiro e irrigado). Piracicaba, Associação Brasileira para Pesquisa da Potassa e do Fosfato, 1987. 120p. (Boletim Técnico, 9).

BATAGLIA, O. C. Micronutrientes: disponibilidade e interações. In: SIMPÓSIO DE ENXOFRE E MICRONUTRIENTES NA AGRICULTURA BRASILEIRA, 1., Londrina, 1988. Anais. Londrina: EMBRAPA, CNPSo; IAPAR; SBCS, 1988. p.121-132.

BATAGLIA, O.C.; RAIJ, B. van. Eficiência de extratores na determinação de B em solos. Revista Brasileira de Ciência do Solo, v.14, p.25-31, 1990. 
BATAGLIA, O.C.; RAIJ, B. van. Soluções extratoras na avaliação da fitodisponibilidade de zinco em solos. Revista Brasileira de Ciência do Solo, v.18, p.457-461, 1994.

BORKERT, C. M. Micronutriente na planta. In: BÜLL, L. T.; ROSOLEM, C. A., (Ed.) Interpretação da análise química do solo e planta para fins de adubação. Botucatu: Fundação de Estudos e Pesquisas Agrícolas e Florestais, 1989. p.309-329.

BRITTO, D.P.P.S.; CASTRO, A.F. de.; NERY, C.; COSTA, A.C. Ensaio de adubação de milho em Latossolo Vermelho-Amarelo sob vegetação de cerrado. Pesquisa Agropecuária Brasileira. Ser. Agron., v.6, p.203-207, 1971.

BÜLL, L. T. Influência da relação $\mathrm{K} /(\mathrm{Ca}+\mathrm{Mg})$ do solo na produção e na absorção de potássio por gramínea e leguminosa forrageiras. Piracicaba, 1986. 107p. Tese (Doutorado) Escola Superior de Agricultura "Luiz de Queiroz", Universidade de São Paulo.

BÜLL, L. T. Nutrição mineral do milho. In: BÜLL, L.T.; CANTARELLA, H. Cultura do milho: fatores que afetam a produtividade. Piracicaba, Associação Brasileira para Pesquisa da Potassa e do Fosfato, 1993. p. 63145.

BUZETTI, S. Estudo da eficiência de extratores químicos de zinco, no solo, para milho. Revista Brasileira de Ciência do Solo, v.16, p.367-372, 1992.

CAMARGO, O. A. Micronutrientes no solo In: SIMPÓSIO DE ENXOFRE E MICRONUTRTIENTES NA AGRICULTURA BRASILEIRA, 1., Londrina, 1988. Anais. Londrina: EMBRAPA, CNPSo; IAPAR; SBCS, 1988. p.10320.

CAMARGO, O. A.; MONIZ, A. C.; JORGE, J. A.; VALADARES, J. A. M. S. Métodos de análise química, mineralógica e física de solos do Instituto Agronômico. Campinas: IAC, 1986. 94p. (Boletim Técnico, 106).

CASTRO, O.M.; CAMARGO, A.O. CANTARELLA, H.; VIEIRA, S.R.; DECHEN, S.C.F. Teores de zinco, cobre, manganês e ferro em dois latossolos sob plantio direto e convencional. Bragantia, v.51, p.77-84, 1992. 
COUTO, C.; NOVAIS, R.F.; TEIXEIRA, J.L.; BARROS, N.F.; NEVES, J.C.L. Níveis críticos de zinco no solo e na planta para $\cdot$ o crescimento de milho em amostras de solos com diferentes valores do fator capacidade. Revista Brasileira de Ciência do Solo, v.16, p.79-88, 1992.

COX, F.R.; KAMPRATH, E.J. Pruebas de micronutrientes en suelos. In: MORTVEDT. J. J.; GIORDANO, P. M.; LINDSAY, W. L. Micronutrientes en Agricultura. Madison: Soil Science Society of America,1983. p.317-347.

DAVIES, B.E. Radish as an indicator plant for derelict land: uptake of zinc at toxic concentration. Communications in Soil Science and Plant Analysis, v.24, p.1883-1895, 1993.

DECARO, S. T.; VITTI, G. C.; FORNASIERI FILHO, D.; MELLO, W. J. Efeito de doses e fontes de zinco na cultura de milho (Zea mays). Revista de Agricultura, v.58, n.1/2, p.25-36, 1983.

DECHEN, A. R. Micronutrientes; funções nas plantas. In: FERREIRA, M. E., coord. SIMPÓSIO SOBRE MICRONUTRIENTES NA AGRICULTURA, 1., Jaboticabal, 1988. Jaboticabal: UNESP, FCA, 1988. p.111-132.

DHILLON, K.S.; YAGODEEN, B.A.; PLESHKOV, A.C. Micronutrients and nitrogen metabolism. I. Effects of different levels of micronutrients on nitrogen constituents in maize plants. Plant and Soil. v.73, p.355-363, 1983.

DRAGUN, J.; BAKER, D. E.; RISIUS, M. L. Growth and element accumulation by two single-cross corn hybrids as affected by copper in solution. Agronomy Journal, v.68, n.3, p.466-470, 1976.

EMPRESA BRASILEIRA DE PESQUISA AGROPECUÁRIA. Centro Nacional de Pesquisa de Solos. Manual de métodos de análise de solo. Rio de Janeiro, 1997. 212p. (EMBRAPA, CNPS. Documentos, 1).

FLEMING, G.A. Essential micronutrients I: boron and molybdenum. In: DAVIES, B. E. (Ed.) Applied soil trace elements. Chichester: John Wiley, 1980. cap.5, p.155-197.

GALLO, J.R.; HIROCE, R.; MIRANDA, L.T. de. A análise foliar na nutrição do milho: resultados de ensaios de adubação com N-P-K-S e micronutrientes. Bragantia, v.24, p.LXXI-LXXVII, 1965. 
GALLO, J.R.; IGUE, T.; BATAGLIA, O.C.; FURLANI, A.M.C.; MIRANDA, L.E.C. Influência do uso contínuo de fertilizantes na nutrição mineral do milho híbrido IAC Hmd/6999B. In: CONGRESSO BRASILEIRO DE CIÊNCIA DO SOLO. 15., Campinas, 1975. Anais. Campinas: Sociedade Brasileira de Ciência do Solo, 1976. p.245-254.

GALRÃO, E.Z. Efeito de micronutrientes e do cobalto na produção e composição química do arroz, milho e soja em solo de cerrado. Revista Brasileira de Ciência do Solo, v.8, n.1, p.111-116, 1984.

GALRÃO E.Z. Resposta das culturas aos micronutrientes boro e zinco. In: SIMPÓSIO DE ENXOFRE E MICRONUTRTIENTES NA AGRICULTURA BRASILEIRA, 1., Londrina, 1988. Anais. Londrina: EMBRAPA, CNPSo; IAPAR; SBCS, 1988. p.205-237.

GALRÃO, E.Z. Níveis críticos de zinco para o milho cultivado em Latossolo Vermelho-Amarelo, fase cerrado. Revista Brasileira de Ciência do Solo, v.19, p.255-260, 1995.

GALRÃO, E.Z. Métodos de aplicação de zinco e avaliação de sua disponibilidade para o milho num Latossolo Vermelho-Escuro, argiloso fase cerrado. Revista Brasileira de Ciência do Solo, v.20, p.283-289, 1996.

GALRÃO E.Z; MESQUITA FILHO M.V. de. Efeito de micronutrientes na produção e composição química do arroz (Oriza sativa) e do milho (Zea mays) em solo de cerrado. Revista Brasileira de Ciência do Solo, v.5, p.7275,1981 .

GALRÃO E.Z.; SOUZA, D.M.G. de.; PERES, J.R.R. Caracterização de deficiências nutricionais em solos de várzeas da região dos cerrados. Pesquisa Agropecuária Brasileira, v.19, p.1091-1101, set. 1984.

GUPTA, U.C. Boron deficiency and toxicity symptoms for several crops as related to tissue boron levels. Journal of Plant Nutrition, v.6, p. 387-395, 1983.

JACINTHO, A.O.; CATANI, R.A.; PIZZINATO, A. Determinação do teor total e do teor solúvel em diversas soluções, do cobre do solo. Anais da Escola Superior de agricultura "Luiz de Queiroz", v.26, p.99-117, 1969. 
JACINTHO, A.O.; CATANI, R.A.; PIZZINATO, A. Extração e determinação do teor solúvel de $\mathrm{Zn}$ do solo. Anais da Escola Superior de agricultura "Luiz de Queiroz", v.28, p.275-285, 1971

KABATA-PENDIAS, A; PENDIAS, H. Trace elements in soil and plants. Boca Raton: CRC Press, 1984. 315p.

KEREN, R.; BINGHAM, F.T.; J. D. Effect of clay content in soil on boron uptake and yield of wheat. Soil Science of America Journal, v.49, n.6, p.1466-1470, 1985.

KIEKENS, L. Zinc. In: ALLOWAY, B.J. (Coord.) Heavy metals in soils. New York: John Wiley, 1990. p.261-277.

LANTMANN, A.F.; MEURER, E.J. Estudo da eficiência de extratores para avaliação do zinco disponivel do solo para o milho. Revista Brasileira de Ciência do Solo, v.6, p.131-135, 1982.

LINDSAY, W.L. Equilibrio de la fase inorgánica de los micronutrientes en suelos. In: MORTVEDT, J.J.; GIORDANO, P.M.; LINDSAY, W.L. (Ed.) Micronutrientes en agricultura, Madison: Soil Science Society of America, 1983. p.45-63.

LINDSAY, W.L.; NORVELL, W. Development of DTPA soil test for zinc, iron, manganese and copper. Soil Science Society of America Journal, v.42, p.421-428, 1978.

LIU, X.B.; YANG, Q.; CHU, T.D.; WANG, S.H.; LI, S.R.; WU, X.F. Effect of zinc application on maize. Acta Pedológica Sinica, v.30, p.153-163, 1993. Suplement. /Resumo em CAB Abstracts on CD-ROM, 1996 - 1998/.

LOPES, A.S. Solos sob "cerrado": características, propriedades e manejo. Piracicaba: Instituto da Potassa \& Fosfato, Instituto International da Potassa, 1983. 162p.

LOPES, A.S.; CARVALHO, J.G. Micronutrientes: Critério de Diagnose para solos e plantas, correção de deficiências e excessos. In: SIMPÓSIO DE ENXOFRE E MICRONUTRTIENTES NA AGRICULTURA BRASILEIRA, 1, Londrina, 1988. Anais. Londrina: EMBRAPA, CNPSo; IAPAR; SBCS, 1988. p.133-78. 
MALAVOLTA, E. Manual de calagem e adubação das principais culturas. São Paulo: Agronômica Ceres, 1987. 496p.

MALAVOLTA, E.; VITTI, G.C.; OLIVEIRA, S.A. Avaliação do estado nutricional das plantas: princípios e aplicações. Piracicaba, Associação Brasileira para Pesquisa da Potassa e do Fosfato, 1989. 201p.

MALAVOLTA, E.; VITTI, G.C.; OLIVEIRA, S.A. Avaliação do estado nutricional das plantas: princípios e aplicações. Piracicaba, Associação Brasileira para Pesquisa da Potassa e do Fosfato, 1997. 319p.

MARTENS, D.C.; WERTERMANN, D.T. Fertilizers applications for correting micronutrients deficiencies. In: MICKELSON, S.H. (Ed.) Micronutrients in agriculture. 2.ed. Madison: Soil Science Society of America, 1991. p.54992.

MEHLICH, A. Mehlich 3 soil test extractant: a modification of Mehlich 2 extractant. Communications in Soil Science and Plant Analysis, v.15, p.1409-1416, 1984.

MELSTED, S.W.; MOTTO, H.L.; PECK, T.R. Critical plant nutrient composition values useful in interpretating plant analysis data. Agronomy Journal, v.6, p.17-20, 1969.

MENGEL, K.; KIRKBY, E.A. Principles of plant nutrition. Bern: International Potash Institute, 1987. 687p.

MOZAFAR, A. Boron effect on mineral nutrients of maize. Agronomy Journal. v.81, n.2, p.285-290, 1989.

MURAOKA, T.; NEPTUNE, A.M.L.; NASCIMENTO, V.F. Avaliação da disponibilidade de zinco e de manganês do solo para o feijoeiro. I. Zinco. Revista Brasileira de Ciência do Solo, v.7, p.167-175, 1983.

PINAZZA, L.A Perspectivas da cultura do milho e do sorgo no Brasil. In: BÜLL, L.T.; CANTARELLA, H. Cultura do milho: fatores que afetam a produtividade. Piracicaba: Associação Brasileira para Pesquisa da Potassa e do Fosfato, 1993. p.01-10 
RAIJ, B. van.; BATAGLIA, O.C. Análise química do solo para micronutrientes. In: SIMPÓSIO SOBRE MICRONUTRIENTES NA AGRICULTURA, Jaboticabal, 1988. Jaboticabal: UNESP, FCA, 1988. v. 2, p.537-569..

RAIJ, B. van.; BATAGLIA, O.C. Análise química do solo. In: FERREIRA, M.E.; CRUZ, M.C.P. (Ed.) Micronutrientes na Agricultura. Piracicaba: POTAFOS/CNPq, 1991. P.334-355.

RAIJ, B. van.; QUAGGIO, J.A. Métodos de análise do solo para fins de fertilidade. Campinas: Instituto Agronômico, 1983. 31p. (IAC. Boletim Técnico, 81).

RAIJ, B. van; CANTARELlA, H.; QUAGGIO, J.A.; FURLANI, A..M.C. Recomendações de adubação e calagem para o Estado de São Paulo. Campinas: Instituto Agronômico, 1996. 285p.

RIBEIRO, A.C.; TUCUNANGO SARABIA, W.A. Avaliação de extratores para zinco e boro disponíveis em latossolos do Triângulo Mineiro. Revista Brasileira de Ciência do Solo, v.8, p.85-89, 1984.

RITCHEY, K.D.; COX, F.R.; GALRÃO, E.Z.; YOST, R.S. Disponibilidade de zinco para as culturas de milho, sorgo e soja em Latossolo Vermelho-Escuro Argiloso. Pesquisa Agropecuária Brasileira, v.21, n.3, p.215-225, 1986.

SARRUGE, J.R. Soluções nutritivas. Summa Phytopatológica, v.1, n.3, p.231233, 1975.

SARRUGE, J.R.; HAAG, H.P. Análises químicas em plantas. Piracicaba: ESALQ, 1974. 56p.

SMILDE, K.W.; VAN LUIT, B. VAN-DRIEL, W. The extraction by soil and adsoption by plants of applied zinc and cadmium. Plant and Soil, v.143, p.233-238, 1992.

TERMAN, G.L.; GIORDANO, P.M.; ALLEN, S.E. Relationships between dry matter yields and concentrations of $\mathrm{Zn}$ and $\mathrm{P}$ in young corn plants. Agronomy Journal, v.64, n.2, p.684-687, 1972.

TOUCHTON, J.T.; BOSWELL, F.C. Boron application for corn grown on selected southeastern soils. Agronomy Journal, v.67, n.2, p.197-200, 1975. 
TRANI, P.E.; HIROCE, R.; BATAGLIA, O C. Análise foliar: amostragem e interpretação. Campinas: Fundação Cargill, 1983. 18p.

VALADARES, J.M.A.S.; CATANI, R.A. Zinco em solos do Estado de São Paulo. I. Zinco total. Bragantia, v.34, p.133-139, 1975.

VIETS JUNIOR, F.G.; LINDSAY, W.L. Testing soils for zinc, copper, manganese, and iron. In: WALSH, L.M.; BEATON, J.D. (Ed.) Soil testing and plant analysis. Madison, Soil Science Society of America, 1983. p.153172.

VOLKWEISS, S.J. Fontes e métodos de aplicação. In: Micronutrientes na Agricultura. Piracicaba: POTAFOS; CNPq, 1991. p.391-496.

WEAR, K.; EVANS, C. Relationship of zinc uptake by corn and sorghum to soil zinc measured by three extractants. Soil Science Society of America Proceedings, v.32, p.543-546, 1968.

WOODRUFF, J.R.; MOORE, F.W.; MUSEN, H.L. Potassium, boron, nitrogen, and lime effects on corn yield and earleaf nutrient concentrations. Agronomy Journal, v.79, n.3, p.520-524, 1987. 